\title{
Buried Treasure: Excavating Foreign Law from Civil Pleadings Filed in U.S. Federal Courts
}

\author{
LOREN TURNER*
}

\section{INTRODUCTION}

Early last summer, I received a phone call from a law student in the litigation department of a large firm. He was working with a team on a case involving Czech law and, as part of a due diligence review, he was seeking an English translation of a piece of Czech legislation before the firm outsourced the bulk of the foreign legal research to Czech attorney-experts. Although it was easy to find the Czech legislation in Czech from a Czech government website, we could not find an English translation - official or otherwise - from any of our free or subscriptionbased databases. In the end, we relied on the flawed magic of Google Chrome's translate feature to "translate" the Czech legislation from the Czech government website into English. Despite my protestations and disclaimers, the student was thrilled with our results and insisted he had satisfied his due diligence duties. I hung up the phone and thought to myself: certainly, other American litigants have taken cases involving Czech law. What happens to the foreign law and legal analysis they obtain from their Czech attorney-experts? Assuming they submit some of it to our U.S. courts in the course of litigation, why can't we easily retrieve it?

Then, in June of 2018, the U.S. Supreme Court issued a decision in Animal Science Products, Inc. v. Hebei Welcome Pharmaceutical, Co. ${ }^{1}$ The Animal Science case began thirteen years ago when American purchasers of Vitamin $\mathrm{C}$ products sued the Chinese manufacturers that export those Vitamin $\mathrm{C}$ products. ${ }^{2}$ The lawsuit accused the Chinese manufacturers of establishing a price-fixing cartel in violation of antitrust laws. ${ }^{3}$ The Chinese manufacturers did not deny the antitrust violations, but relied on Chinese law in their defense. ${ }^{4}$ In support of the Chinese defendants, the Chinese government filed an amicus brief with an official interpretation of the applicable Chinese law. ${ }^{5}$ The Eastern District Court of New York found discrepancies among the documents provided by the defendants and refused to defer to the interpretation of the Chinese law by the Chinese government. ${ }^{6}$ The case went to trial and a

* (C) Loren Turner 2019. The author is Foreign, Comparative, and International Law Librarian at the University of Minnesota Law School. My thanks to my colleagues at UMN law library for reviewing and commenting upon an earlier draft of this article and especially to Connie Lenz for her consistent support and insight. All faults lie with the author.

1585 U.S. _ (2018), 138 S.Ct. 1865 (2018) (hereinafter, Animal Science).

2 The case began in 2005 with three separate class action lawsuits filed in three different U.S. federal district courts (Philion v. Hebei Welcome Pharmaceutical Co., Ltd., et al., No. 05-4524 (N.D. Cal. Nov. 7, 2005); Audette v. Hebei Welcome Pharmaceutical Co. Ltd., et al., No. 05-12224 (D. Mass. Nov. 7, 2005); Animal Science Products, Inc. et al. v. Hebei Welcome Pharmaceutical Co. Ltd. et al., No. 05-cv-00453 (E.D.N.Y. Jan. 26, 2005). The cases were then consolidated in In re Vitamin C Antitrust Litigation, No. 06-md-07138 (E.D.N.Y. Feb. 22, 2006).

3 See 585 U.S. (2018), 138 S.Ct. 1865, 1870 (2018).

${ }^{4}$ See 585 U.S. —— (2018), 138 S.Ct. 1865, 1870 (2018).

${ }^{5}$ See 585 U.S. ____ (2018), 138 S.Ct. 1865, 1870 (2018). See also In re Vitamin C Antitrust Litigation, 584 F.Supp.2d 546, 552 (2008) ("The Chinese government's appearance as amicus curiae is unprecedented").

${ }^{6}$ See 585 U.S._____ (2018), 138 S.Ct. 1865, 1871-2 (2018). See also In re Vitamin C Antitrust Litigation, 584 F.Supp.2d 546, 557 (E.D.N.Y. 2008) ("The Ministry's Brief is, therefore, entitled to substantial deference, but will not be taken as conclusive evidence of compulsion, particularly where, as here, the plain language of the documentary evidence submitted by plaintiffs directly contradicts the Ministry's position."). 
jury awarded $\$ 147$ million dollars in damages. ${ }^{7}$ On appeal, the Second Circuit reversed, arguing that it was bound to defer to the Chinese government's interpretation of its own law. ${ }^{8}$ On certiorari, the U.S. Supreme Court was asked to identify the level of deference U.S. courts should give a foreign sovereign's interpretation of its own law. ${ }^{9}$ The U.S. Supreme Court held that U.S. courts should give "respectful consideration" to the foreign sovereign's interpretation, but are not bound to it. ${ }^{10}$ The U.S. Supreme Court vacated and remanded the case back to the Second Circuit. ${ }^{11}$

Thus far, legal analysis of the Animal Science case focuses on the arguments of the parties and the standard set by the U.S. Supreme Court. ${ }^{12}$ But, no one is talking about all those documents in the case's multiple dockets that provide the content, interpretation, and analysis of Chinese law. The sophisticated parties in this dispute spent thirteen years (and counting) on gathering Chinese law. These documents are rich reserves of material for every future scholar, librarian, and/or practitioner seeking information on Chinese law and yet, they remain buried among all the other filings in the case's lengthy court files.

The Animal Science case is one of many cases in U.S. federal courts wherein parties rely in some measure on foreign law as part of a claim or defense. Yet, none of our legal research databases tracks and catalogs the foreign law and legal analysis filed in our courts. ${ }^{13}$ In fact, none of our legal research databases even provides an efficient way to find the foreign law and legal analysis filed in our courts. ${ }^{14}$ Despite the increasing frequency of cross-border litigation and the various types of cases that trigger a need to determine foreign law, access to foreign law as filed in our courts remains limited. ${ }^{15}$ Additionally, although several wonderful foreign legal research databases exist, they do not offer up-to-date certified translations of foreign law or expert interpretations and analysis by foreign counsel. Our court records do. The purpose of this article is to raise awareness that litigants in U.S. courts are producing documentation of foreign law with increasing frequency and that those documents are valuable and should be more accessible to future litigants, practitioners, scholars, and researchers.

This article proceeds in six parts. Following this introduction, Part II gives an overview of international comity, a common law doctrine that guides the recognition of foreign law in our U.S. courts. ${ }^{16}$ Additionally, Part II offers a taxonomy of cases that trigger a need to research foreign law. Although both state and federal courts receive documents regarding the content, interpretation, and analysis of foreign law, ${ }^{17}$ existing legal research databases do not provide full coverage examination of state court case dockets and, for that reason, the taxonomy in Part II focuses only on civil cases filed in U.S. federal courts. Part III traces the development and application of Rule 44.1 of the Federal Rules of Civil

${ }^{7}$ See 585 U.S. _____ (2018), 138 S.Ct. 1865, 1871-2 (2018) (also noting that the jury issued a permanent injunction from further violations of the Sherman Act).

${ }^{8}$ See 585 U.S. _ _ _ (2018), 138 S.Ct. 1865, 1872 (2018).

9 See 585 U.S. —— (2018), 138 S.Ct. 1865, 1872 (2018).

${ }^{10}$ See 585 U.S. —— (2018), 138 S.Ct. 1865,1869 (2018).

${ }^{11}$ See 585 U.S. ___ (2018), 138 S.Ct. 1865, 1875 (2018) ("The correct interpretation of Chinese law is not before this Court, and we take no position on it. But the materials identified by the District Court were at least relevant to the weight the Ministry's submissions should receive and to the question whether Chinese law required the Chinese sellers' conduct").

12 See e.g., Amy Howe, Opinion Analysis: "Respectful consideration," but not deference, required on foreign-law questions, SCOTUSBLog (June 14, 2018), http:/www.scotusblog.com/2018/06/opinion-analysis-respectful-consideration-but-notdeference-required-on-foreign-law-questions/; Ted Folkman, Case of the Day: Animal Science Products v. Hebei Welcome, LetTERS BlOGATORY (June 15, 2018), https://lettersblogatory.com/2018/06/15/case-of-the-day-animal-science-products-vhebei-welcome/; Scott R. Anderson, Deference and Foreign Law in In re Vitamin C, LAwFARE (Nov. 17, 2017), https:// www.lawfareblog.com/deference-and-foreign-law-re-vitamin-c).

${ }^{13}$ For the purposes of this article, the phrase "foreign law" refers to the law of a foreign sovereign.

${ }^{14}$ See Part IV, below.

15 See Philip D. Stacey, Rule 44.1., Bodum USA v. La Cafetiere, and The Challenge of Determining Foreign Law, 6 SEVENTH CIR. Rev. 472, 479 (2011) (“... as the world has become more globalized, national boundaries are becoming less important, resulting in a rapid increase in the number of foreign law cases in domestic courts. Just as people are no longer surprised to see German cars on American roads, or Chinese household goods on Wal-Mart shelves, people should no longer be surprised to see cases that turn on interpretations of German or Chinese law being decided by American courts").

${ }^{16}$ See Thomas Schultz \& Niccolò Ridi, Comity in US Courts, 10 NE. U. L. Rev. 280, 282 (2018) (noting that the concept of comity is "[s]ometimes labelled as a "principle," sometimes as a "doctrine").

${ }^{17}$ See e.g., Jorge A. Vargas, The Emerging Presence of Mexican Law in California Courts, 7 SAN DIEGO INT'L L.J. 215,218 (2005) ("In a quick search for cases involving foreign law that have been decided by California courts over the last two years... 100 cases were governed by Mexican law, 57 by Canadian law, 29 by Japanese law, 28 by German law, and 12 by Chinese law”). 
Procedure, a key to unlocking the vault of documents on foreign law and legal analysis filed in U.S. federal courts. Part IV of this article outlines available methods for finding and organizing foreign law filed in our U.S. federal courts, based on combined use of the top three legal research databases in the American legal academy: Bloomberg Law, Westlaw, and Lexis Advance. Part V concludes this article and Part VI contains an appendix with a prototype for a future reference source that extracts and organizes foreign law filed in our U.S. federal courts.

\section{International Comity and A Taxonomy of Civil Cases in U.S. Federal Court that Consider FOREIGN LAW}

Civil litigants (and judges) in U.S. federal court consider the law of a foreign sovereign in an array of circumstances for a variety of reasons. ${ }^{18}$ International comity is the theoretical foundation underlying the treatment of foreign sovereigns and foreign law by U.S. federal courts. ${ }^{19}$ Section A, below, provides an overview of international comity as it is understood by courts and scholars today. Following the discussion of international comity, section B provides a taxonomy of cases that give rise to party pleadings and judicial opinions that provide and construe foreign law. The taxonomy is not necessarily comprehensive and there is overlap between the categories, but the groupings demonstrate the breadth of topics that can trigger production and consideration of foreign law.

\section{A. Overview of International Comity}

In 1895, in Hilton v. Guyot, ${ }^{20}$ the U.S. Supreme Court identified the concept of international comity as:

"the recognition which one nation allows within its territory to the legislative, executive or judicial acts of another nation, having due regard both to inter-national duty and convenience, and to the rights of its own citizens, or of other persons who are under the protection of its laws." 21

In the subsequent 120 years after Hilton, however, U.S. federal courts failed to agree on the practical contours of international comity, leading to inconsistencies among precedents. ${ }^{22}$ To remedy the confusion, Professor William Dodge recently conducted a study of U.S. federal court cases and synthesized from them a definition of what international comity is today: "[i]nternational comity is deference to foreign government actors that is not required by international law but is incorporated in domestic law." 23

Using this definition, international comity operates as both a principle of recognition and a principle of restraint. ${ }^{24}$ As a principle of recognition, international comity authorizes U.S. federal courts to recognize (and

${ }^{18}$ See Arthur R. Miller, Federal Rule 44.1 and the "Fact" Approach to Determining Foreign Law: Death Knell for a DieHard Doctrine, 65 Mich. L. REv. 613, 616 (1967) ("One important facet of the post-war proliferation of international litigation is a correlative increase in the number of lawsuits in which the law of a foreign country is germane, either because it governs the rights and liabilities of the parties under the relevant conflict-of-laws principles or because it bears on a particular issue or issues in a case otherwise controlled by domestic law"). See also Roger J. Miner, The Reception of Foreign Law in U.S. Federal Courts, 43 Ам. J. Coмp. L. 581, 581 (1995) (listing immigration matters, tort claims, public law disputes, arbitration enforcement proceedings, domestic relation suits and even criminal cases as matters forming a significant part of the business of the federal courts.).

19 See Gil Seinfeld, Reflections on Comity in the Law of American Federalism, 90 Notre Dame L. Rev. 1309, 1309 (2015) (describing comity as a "nebulous concept" and a "regime of intergovernmental courtesy").

20159 U.S. 113 (1895) (hereinafter: Hilton).

${ }^{21}$ Hilton, 159 U.S. 113, 164 (1895).

${ }^{22}$ See William S. Dodge, International Comity in American Law, 115 Colum. L. Rev. 2071, 2072-3 (2015) ("For a principle that plays such a central role in U.S. foreign relations law, international comity is surrounded by a surprising amount of confusion...courts and commentators repeatedly confess that they do not really understand what international comity means. Courts complain that comity "has never been well-defined." They frequently refer to it as "vague" or "elusive."). See also William S. Dodge, International Comity in American Law, 115 ColuM. L. Rev. 2071, 2075, 2089 (describing Hilton's definition of comity as "incomplete and ambiguous" and "slippery.").

${ }^{23}$ William S. Dodge, International Comity in American Law, 115 Colum. L. Rev. 2071, 2078 (2015) (claiming that one of the aims of his article was to "rescue international comity from disrepute").

${ }^{24}$ See William S. Dodge, International Comity in American Law, 115 Colum. L. Rev. 2071, 2078-9 (2015) (charting the treatment of international comity in U.S. courts along X-and Y-axes with the X-axis representing the government actor to whom 
sometimes actually apply) the law of foreign sovereigns. ${ }^{25}$ As a principle of restraint, international comity stops U.S. federal courts from adjudicating cases that infringe on the sovereignty of other nations. ${ }^{26}$ Reciprocal respect among nations is the ultimate goal. ${ }^{27}$

Regardless of whether international comity is acting as a principle of recognition or as a principle of restraint, arguments based on notions of international comity rely on some demonstration of foreign law. As the taxonomy below, in section B, explains, sometimes recognition of foreign law requires actual application of foreign law in U.S. federal court. Application of foreign law is impossible without first determining its content. Moreover, sometimes restraint of U.S. federal court jurisdiction requires proof of foreign legislation (translated, certified, and oftentimes accompanied by expert legal analysis) that demonstrates a foreign sovereign's superiority over certain rights protected under U.S. law.

\section{B. Taxonomy of Civil Cases in U.S. Federal Courts that Consider Foreign Law}

There are several types of cases in which litigants ask federal courts to consider foreign law. These include cases falling under the "conflict of laws" umbrella (choice of law, jurisdiction, and recognition/enforcement cases) as well as cases involving foreign affairs doctrines, federal statutes, treaties, customary international law, and even the U.S. Constitution. The depth of treatment with which a court considers foreign law in these cases runs the gamut between those in which the court merely notes foreign law in a stray citation to those in which courts apply foreign law to the merits of the case.

\section{1. “Choice of Law” Cases}

"Choice of law" cases are a subset of cases involving the "conflict of laws." 28 "Conflict of laws" is a legal term of $\operatorname{art}^{29}$ defined as a "system of jurisprudence which determines which law applies or reconciles inconsistencies

deference may be given and the $\mathrm{Y}$-axis representing the use of international comity as either a principle of recognition or restraint). See also Maggie Gardner, Retiring Forum Non Conveniens, 92 N.Y.U. L. Rev. 390, 392-3 (2017) (translating Dodge's chart as one that distinguishes "positive comity" doctrines that "call on courts to step temporarily into the shoes of foreign sovereigns" from "negative comity" doctrines that "call for restraint on the part of courts to avoid stepping on the toes of foreign states.").

${ }^{25}$ See William S. Dodge, International Comity in American Law, 115 Colum. L. Rev. 2071, 2078-9 (2015) (identifying several foreign affairs doctrines based on international comity that recognize foreign law makers (prescriptive comity), foreign tribunals (adjudicative comity), and foreign governments (sovereign party comity)). See also George T. Yates III, Foreign Law before Domestic Tribunals, 18 VA. J. INT'L L. 725, 725 (1978) (“[r]easons for the willingness of courts to apply foreign law include fairness in recognizing legal relationships created in a foreign country and facilitation of international transactions in an increasingly interdependent world").

${ }^{26}$ See William S. Dodge, International Comity in American Law, 115 Colum. L. Rev. 2071, 2078-9 (2015) (identifying several foreign affairs doctrines based on international comity that restrain U.S. courts and defer to foreign law makers (prescriptive comity), foreign tribunals (adjudicative comity), and foreign governments (sovereign party comity)).

${ }^{27}$ See Sofie Geeroms, Foreign Law in Civil Litigation: A Comparative and Functional Analysis 2 (2004) (“"[t]he way foreign law is treated in a court reveals whether the rights available under a different foreign legal system will be respected after all, which in turn is a touchstone for the question of to what extent a legal system will tolerate foreign legal ideas"). See also JP Morgan Chase Bank, 412 F.3d at 423 (finding that international comity is "shorthand for good neighbourliness, common courtesy and mutual respect between those who labour in adjoining judicial vineyards").

${ }^{28}$ See Restatement (Second) Conflict of Laws $\S 2$ (listing jurisdiction, choice of law, and judgment recognition/enforcement cases as matters falling within the field of conflict of laws). See also Christopher A. Whytock, Myth of Mess - International Choice of Law in Action, 84 N.Y.U. L. Rev. 719, 724 (2009) (defining choice of law as "the branch of conflict of laws doctrine that seeks to identify the appropriate law to apply in disputes with connections to more than one state"); Dodge at 2100-1 (identifying choice of law cases as an example of prescriptive comity operating as a principle of recognition but noting that U.S. courts rarely invoke comity directly when deciding choice of law cases).

29 See Conflict of Laws, in Black's Law Dictionary (Bryan A. Garner, ed., 10th ed. 2014). See also Peter Hay, et AL., Conflict of Laws $\S 1.1\left(6^{\text {th }}\right.$ ed., 2018) (explaining that the term "conflict of laws" is used in the U.S., Canada, and England whereas the term "private international law" is used in the continental countries of Europe to deal with choice of law problems). 
of conflicting laws" 30 in "all situations where the affairs of men cut across state lines." 31 In other words, transactions that occur across state lines or national borders can give rise to disputes involving the laws of more than one state and/or more than one country. ${ }^{32}$ In these cases, courts must decide which law applies and/or reconcile inconsistencies between the laws in order to adjudicate the case. ${ }^{33}$

In 1987, U.S. state and federal courts decided 2,245 cases involving the conflict of laws. ${ }^{34}$ Thirty years later, in 2017, U.S. state and federal courts decided 5,382 cases involving the conflict of laws. ${ }^{35}$ The 140 percent increase in conflict of laws cases results from technological advancements that make it easier for "the affairs of men" to cut across state and national lines, giving rise to more disputes. ${ }^{36}$ Unfortunately, none of the available statistics analyzes those numbers further to show which percentage of conflict of laws disputes result specifically from transnational as opposed to interstate disputes.

Contractual disputes and allegations of tortious conduct are the most common situations wherein litigants disagree on the substantive law that supports their claims or defenses and judges are forced to choose which substantive law applies. ${ }^{37}$ If the parties had a pre-existing contract with a valid choice of law clause, federal courts will apply the law of the country identified in the choice of law clause. ${ }^{38}$ In the absence of a contract with a valid choice of law clause (or in the absence of any contract at all), a court will undertake a choice of law analysis to determine which country's substantive law(s) will govern the issue(s) in dispute. ${ }^{39}$

${ }^{30}$ See Conflict of Laws, in Gilbert Pocket Size Law Dictionary (3d ed. 2014). See also Stephen Yeazell, When and How U. S. Courts Should Cite Foreign Law, 26 Const. Com. 59, 62 (2009) (defining the conflict of laws as an "ancient if sometimes indeterminate body of law").

${ }^{31}$ Restatement (Second) Conflict of Laws, § 2. See also Ernest G. Lorenzen, Story's Commentaries on the Conflict of LawsOne Hundred Years After, 48 HARV. L. REV. 15, 18 (1934) (saying that conflict of laws cases didn't appear before English courts until the middle of the eighteenth century and then started appearing more frequently in England and the U.S. because of the "enormous expansion in trade" in the early nineteenth century.).

32 See Matthew J. Wilson, Demystifying the Determination of Foreign Law in U.S. Courts: Opening the Door to a Greater Global Understanding, 46 WAKE Forest L. REV. 887, 888 (2011) (giving examples of situations where the laws of multiple nations can govern the same conduct or relationships).

${ }^{33}$ See Christopher A. Whytock, Myth of Mess - International Choice of Law in Action, 84 N.Y.U. L. REV. 719,728 (2009) (explaining that in the United States, each state has its own choice of law rules, so federal courts sitting in diversity look to the rules of the state in which they sit; federal courts not sitting in diversity generally follow the Second Restatement.). See also George T. Yates III, Foreign Law before Domestic Tribunals, 18 VA. J. INT'L L. 725, 725-6 (1978) (confirming that the forum's rules govern the application of foreign law); Stephen L. Sass, Foreign Law in Federal Courts, 29 Am. J. Comp. L. 97110 (1981) (highlighting that when a court applies foreign law, it enforces domestic law because "the law of a foreign country is not applicable unless the domestic conflicts rules call for its application.").

${ }^{34}$ See Symeon C. Symeonedis, Choice of Law in the American Courts in 2017: Thirty-First Annual Survey, 66 Am. J. Comp. L. 1, 4 (2018).

${ }^{35}$ See Symeon C. Symeonedis, Choice of Law in the American Courts in 2017: Thirty-First Annual Survey, 66 Am. J. Comp. L. 1, 3-4 (2018) (noting that 70\% of these cases were decided by federal district courts but that those federal district court decisions are (unfortunately) not covered in the survey).

${ }^{36}$ See Symeon C. Symeonedis, Choice of Law in the American Courts in 2017: Thirty-First Annual Survey, 66 Am. J. ComP. L. 1, 4 (2018). See also SAGI PEARI, THE FOUNDATION OF CHOICE OF LAW: CHOICE AND EQUALITY Xv-xvi (2018) ("We live in a world where it is extremely difficult to find a purely domestic case: people come from different places, they travel and engage in cross-border commerce, they make online deals, and goods are manufactured in multiple geographic locations. Private international law is booming in present-day reality, and its implications for social conditions and practitioners (and subsequently the public) are significant"). But see Yuko Nishitani, Treatment of Foreign Law: Dynamics Towards Convergence? - General Report, in Treatment of Foreign LAW - Dynamics towards Convergence? 3, 10 (Nishitani, ed. 2017) (suggesting that arbitration may be the more preferred method of resolving cross-border disputes).

${ }^{3}$ See Symeon C. Symeonedis, Choice of Law in the American Courts in 2017: Thirty-First Annual Survey, 66 Am. J. Comp. L. 1, 4 (2018) (providing graphics of torts and contracts cases involving "choice of law" disputes over time).

38 See Matthew J. Wilson, Demystifying the Determination of Foreign Law in U.S. Courts: Opening the Door to a Greater Global Understanding, 46 WAKE Forest L. REV. 887, 890 (2011) (noting that courts will honor agreements to apply the law of the selected forum). See also Stephen Yeazell, When and How U.S. Courts Should Cite Foreign Law, 26 Const. Com. 59, 61-2 (2009) (explaining that under existing law, courts will honor choice of law clauses in contracts even when the law is foreign).

39 See 9A Wright \& Miller, Fed. Prac. \& Proc. Civ. § 2442 (3d ed. Apr. 2018 Supp.) (saying that in diversity of citizenship cases, a federal court applies the conflict of laws statute of the state in which its sits). See also Thomas O. Main, The Word 
Under the choice of law analysis, a judge weighs a series of non-dispositive factors to decide whether to apply foreign law or U.S. law (also called the forum law) ${ }^{40}$ The party arguing for the application of foreign law will provide the court with documentation of foreign law in an effort to persuade the judge that the foreign law governs the case and is appropriate, accessible, and "easily" applied. ${ }^{41}$ If the court agrees that foreign law forms the substantive law of the dispute, both opposing counsel and, sometimes, the judge, herself, will research and produce foreign law and analysis for the record. ${ }^{42}$ Regardless of a judge's ultimate decision of whether to apply or avoid foreign law under a choice of law analysis, the dockets of choice of law cases often provide rich sources for extracting foreign law and legal analysis because at least one of the parties is arguing that foreign law is not only relevant to an issue, but also provides the mandatory, governing law.

\section{Jurisdiction Cases}

Some cases involving the jurisdiction of federal courts also fall under the "conflict of laws" umbrella. Article III, section 1 of the U.S. Constitution created the U.S. Supreme Court and gave Congress the power to create a system of "inferior [c]ourts" below. ${ }^{43}$ In response, Congress created a two-level court system under the U.S. Supreme Court, consisting of federal district courts and federal circuit courts. ${ }^{44}$ Federal district courts are the trial courts that receive party pleadings, hold hearings, and issue rulings on claims and defenses. ${ }^{45}$ Federal circuit courts are the intermediate courts that hear appeals from district court decisions. ${ }^{46}$ All federal courts are courts of

Commons and Foreign Laws, 46 CoRnelL InT'L L.J. 219, 271-2 (2013) (highlighting the incredible amount of discretion judges have in weighing the factors of a choice of law analysis); Louise Ellen Teitz, Determining and Applying Foreign Law: The Increasing Need for Cross-Border Cooperation, 45 N.Y.U. J. INT'L L. \& Pol. 1081, 1082-3 (2013) (distinguishing between "ascertaining the content of foreign law (the evidentiary aspect) and determining whose law ought to be applied (the choice of law aspect,")). But see John R. Brown, 44.1 Ways to Prove Foreign Law, 9 MAR. Law. 179, 179 (1984) (saying that the evidentiary and choice of law aspects of pleading and proving foreign law intertwine).

${ }^{40}$ See Yuko Nishitani, Treatment of Foreign Law: Dynamics Towards Convergence? - General Report, in Treatment OF Foreign Law - Dynamics towards Convergence? 3, 6 (Nishitani, ed. 2017) (explaining that foreign law applies when the forum state's choice of law rules require it). See also Christopher A. Whytock, Myth of Mess - International Choice of Law in Action, 84 N.Y.U. L. Rev. 719,728 (2009) (reiterating that a federal court sitting in diversity applies the choice of laws analysis of the state in which it sits, but in non-diversity cases, federal courts follow the Restatement (Second).

${ }^{41}$ See John G. Sprankling \& George R. Lanyi, Pleading and Proof of Foreign Law in American Courts, 19 Stan. J. InT'L L. 3, 10 (1983) (warning that attorneys must be prepared for judges eager to avoid applying foreign law in favor of the familiar law of the forum).

${ }^{42}$ When a federal judge chooses to apply the law of a foreign country, her goal is to step into the shoes of the judge in that foreign country and interpret and apply the foreign law as would the foreign judge. See John R. Schmertz Jr., The Establishment of Foreign and International Law in American Courts: A Procedural Overview, 18 VA. J. InT'L L. 697, 715 (1978) (“The ultimate goal of researching foreign law is to predict how the authoritative organs of that country would decide the point in question."). See also Gregory S. Alexander, Application and Avoidance of Foreign Law in the Law of Conflicts, 70 Nw. U. L. REv. 602, 630-1 (1976) (explaining that adherence to the principle that domestic courts should interpret foreign law as would foreign courts promotes the goal of uniform results, minimizing conflicting or inconsistent decisions); Christopher A. Whytock Myth of Mess - International Choice of Law in Action, 84 N.Y.U. L. Rev. 719, 765, tbl. 2 (finding that U.S. judges are not as biased in favor of forum law as they supposedly once were and actually apply foreign law in transnational tort cases at an estimated rate of $44.5 \%$.).

${ }^{43}$ U.S. Const., Art. III, § 1. See also U.S. Const., Art. III, § 2 (identifying the subject matter jurisdiction of federal courts).

${ }^{44}$ See Act of Sept. 24, 1789, 1 Stat. 73. See also 13 Wright \& Miller, Fed. Prac. \& Proc. Juris. $\$ 3503$ to 3504 (providing background information on The Judiciary Act of 1789 and noting subsequent Congressional actions relating to the organizational structure of the federal system).

${ }^{45}$ See 28 U.S.C. $\S \S 81$ to $\S 131$ (detailing the division of district courts across the U.S.). See also http://www.uscourts.gov/ about-federal-courts/court-role-and-structure; 13 Wright \& Miller, Fed. Prac. \& Proc. JuRis. $§ 3505$ (explaining in detail the U.S. district court system as created by Congress in 28 U.S.C.A. $\S \S 81$ to 131)).

${ }^{46}$ See http://www.uscourts.gov/about-federal-courts/court-role-and-structure. See also 13 Wright \& Miller, Fed. Prac. \& Proc. JuRIs. § 3506 . 
limited jurisdiction; ${ }^{47}$ they must have personal jurisdiction over all the parties ${ }^{48}$ as well as subject matter jurisdiction over the claims and defenses that form the basis of the lawsuit. ${ }^{49}$

In transnational disputes, subject matter jurisdiction based on a federal statute or diversity of citizenship are the most likely ways for litigants to get their cases heard in U.S. federal district court. Subject matter jurisdiction based on a federal statute is relatively straightforward; disputes arising under federal statutes belong in federal court. ${ }^{50}$ For example, the Eastern District of New York had subject matter jurisdiction in the Animal Science case because plaintiffs alleged antitrust violations under the Sherman Act, which is a federal statute prohibiting anti-competitive behavior in the marketplace. ${ }^{51}$ On the other hand, subject matter jurisdiction based on diversity of citizenship does not have to involve a federal statute. ${ }^{52}$ Subject matter jurisdiction based on diversity of citizenship simply requires that the amount in controversy exceeds $\$ 75,000$ and that the parties on either side of the dispute are citizens of different U.S. states or citizens of the U.S. and of a foreign state. ${ }^{53}$ In cases involving diversity jurisdiction disputes, parties may produce foreign law (in particular, the nationality laws of foreign sovereigns) to prove (or disprove) citizenship for the purpose of establishing (or denying) diversity jurisdiction exists.

Moreover, even when, technically, a U.S. federal court has proper jurisdiction, litigants may assert arguments based on notions of international comity to persuade a court to abstain from exercising its jurisdiction. ${ }^{54}$ One of the most popular examples is the doctrine of forum non conveniens. ${ }^{55}$ The doctrine of forum non conveniens allows a federal court to dismiss a case from its docket if it determines that another sovereign's court system also has jurisdiction and is better able to adjudicate the case. ${ }^{56}$ Cases involving foreign law and/or foreign parties are

${ }^{47}$ See Marbury v. Madison, 5 U.S. 137 (1803) (finding that the U.S. Constitution identifies the limits of judicial power). See also Restatement (Second) Conflict of Laws, $\S 2$ (noting that each state determines the rules to the types of cases involving foreign elements that its courts and tribunals can hear).

${ }^{48}$ See Int'l Shoe v. State of Washington, 326 U.S. 310, 316 (1945) (requiring a defendant to have "minimum contacts" with the forum so that the lawsuit doesn't offend "traditional notions of fair play and substantial justice"). See also Daimler AG v. Bauman, 571 U.S. 117, 122 (2014) (limiting general jurisdiction to instances in which the defendant's contacts with the forum state are so continuous and systematic as to render it "essentially at home" there."); 13 Wright \& Miller, Fed. Prac. \& Proc. JuRIS., § 1063.

49 See 13 Wright \& Miller, Fed. Prac. \& Proc. Juris. $\S 3561$ to 3713 (outlining requirements for subject matter jurisdiction). See also 28 U.S.C. § 1332(a)(2) (granting district courts with original jurisdiction over civil actions in which the amount in controversy exceeds $\$ 75,000$ and the dispute is between "citizens of a State and citizens or subjects of a foreign state").

${ }^{50}$ See 13 Wright \& Miller, Fed. Prac. \& Proc. Juris. § 3561 et al.

${ }^{51}$ Sherman Anti-Trust Act, 15 U.S.C. $\S 1$ et al.

52 See 13 Wright \& Miller, Fed. Prac. \& Proc. $\S 3601$ et al.

${ }^{53}$ See 28 USC $\S 1332$ (a). The Supreme Court has held that this requires "complete diversity." See Strawbridge v. Curtiss, 7 U.S. (3 Cranch) 267 (1806) (Marshall, C.J.). But see Cabalceta v Standard Fruit Co. (11th Cir. 1989) (saying that diversity is destroyed if there are aliens on both sides).

${ }^{54}$ See e.g., Part II.B.4, below. See also Foreign Sovereign Immunities Act, Pub. L. 94-583 (Oct. 21, 1976) as codified in 28 U.S.C. $\S 1330,1602-11$ (requiring dismissal of suits against foreign states unless relevant exceptions apply).

55 See Maggie Gardner, Retiring Forum Non Conveniens, 92 N.Y.U. L. Rev. 390, 414-5 (2017) (clarifying that the term "forum non conveniens" is a faux ami because it translates to "inappropriate" or "unsuitable" forum - not "inconvenient forum"). See also Walter W. Heiser, Forum Non Conveniens and Choice of Law: The Impact of Applying Foreign Law in Transnational Tort Actions, 51 WAYNE L. REv. 1161, 1162-3 (2005) (explaining that the forum of non conveniens doctrine developed as a way to protect U.S. defendants from tort lawsuits filed by foreign plaintiffs). As originally conceived, dismissals on the basis of forum non conveniens were supposed to be rare, yet, application of the doctrine in U.S. federal courts over the years have proven otherwise. See Rudy J. Peritz, Determination of Foreign Law under Rule 44.1, 10 Tex. InT'L L.J. 67, 75 (1975) (finding that the federal courts applying FRCP Rule 44.1 within the first eight years of its adoption denied forum non conveniens motions, believing that the rule's mere relevance standard and avoidance of evidence formalities made ascertaining foreign law easy enough to minimize cost and inconvenience). But see Donald Earl Childress III, Forum Conveniens: The Search for a Convenient Forum in Transnational Cases, 53 VA. J. InT'L L. 157, 169 (2012) (finding motions to dismiss for forum non conveniens were granted in 48 percent of reported federal cases between 2007 and 2012).

${ }^{56}$ See Wright \& Miller, Fed. Prac. \& Proc. $\S \S 3828$ - 3828.5 (explaining that a court cannot dismiss a case from its jurisdiction under forum non conveniens grounds unless an "adequate alternative forum" exists and the public and private interest factors set out by precedent weigh in favor of dismissal). See also Walter W. Heiser, Forum Non Conveniens and Choice of Law: The Impact of Applying Foreign Law in Transnational Tort Actions, 51 Wayne L. Rev. 1161, 1172-3 (2005) (finding that 
especially vulnerable to dismissal under the doctrine of forum non conveniens. ${ }^{57}$ Regardless of a case's eventual outcome, however, in forum non conveniens disputes, parties submit documentation and expert analysis on the legal system(s) of foreign jurisdiction(s) to demonstrate or deny that an "adequate alternative forum" exists to adjudicate the dispute. All of that information is submitted to U.S. federal courts and available in the record for future practitioners and scholars.

\section{Recognition and Enforcement of Judgment Cases}

The third subset of cases potentially involving the "conflict of laws" focuses on the post-judgment stage of litigation. ${ }^{58}$ Assuming a case goes all the way to trial and a court issues a decision, the winning party will seek to collect payment. But, when the losing party's assets are located in another forum/country, the winning party must seek recognition and enforcement of the judgment in that other forum/country to receive payment. ${ }^{59}$ Bankruptcy cases, family law (divorce and child support) cases, torts cases, and cases involving commercial contracts often require cross-border recognition and enforcement.

The Restatement (Third) of Foreign Relations Law provides the general rule that foreign judgments are entitled to recognition and enforcement unless there are grounds for non-recognition. ${ }^{60}$ Section 482 of the Restatement (Third) of Foreign Relations Law outlines mandatory and discretionary grounds for non-recognition of foreign judgments. ${ }^{61}$ U.S. courts "may not recognize" a foreign judgment if the foreign court lacked due process protections or personal jurisdiction over the parties. ${ }^{62}$ As discretionary grounds, U.S. courts "need not recognize" a foreign judgment if: "(a) the court that rendered the judgment did not have jurisdiction of the subject matter of the action; (b) the defendant did not receive notice of the proceedings in sufficient time to enable him to defend; (c) the judgment was obtained by fraud; (d) the cause of action on which the judgment was based, or the judgement itself, is repugnant to the public policy of the United States or of the State where recognition is sought; (e) the judgment conflicts with another final judgment that is entitled to recognition; or (f) the proceeding in the foreign court was contrary to an agreement between the parties to submit the controversy on which the judgment is based to another forum." 63

In these types of cases, the party seeking recognition and enforcement of a foreign judgment will provide the U.S. federal district court with copies of the foreign judgment(s) and also, sometimes, with other documentation of foreign law and/or the foreign legal system. Opposing counsel may also produce foreign law, but for the reason of opposing recognition and enforcement of the foreign judgment. Either way, foreign law is filed in the docket and guides the district court judge's decision.

as long as the alternative forum provides some remedy, it will also be deemed adequate); Cassandra Burke Robertson, Transnational Litigation and Institutional Choice, 51 B.C. L. REv. 1081, 1090 (2010) (noting that cases that hinge on forum non conveniens are those in which the public and private interest factors point in different directions).

${ }^{57}$ See Piper Aircraft Co. v. Reyno, 454 U.S. 235, 251-2, 255-6 (1981) (holding that the presumption in favor of the plaintiff's choice of forum does not extend to foreign plaintiffs). See also Maggie Gardner, Retiring Forum Non Conveniens, 92 N.Y. U. L. Rev. 390, 460 (2017) (highlighting the incredible amount of discretion that trial judges have in deciding forum non conveniens disputes and suggesting that this discretion encourages distortion of the doctrine over time because it allows judges to avoid difficult cases); John G. Sprankling \& George R. Lanyi, Pleading and Proof of Foreign Law in American Courts, 19 STAN. J. InT'L L. 3, 11 (1983). (noting that several cases explicitly considered the difficulties in determining foreign law as a reason to dismiss for forum non conveniens.").

${ }^{58}$ See Restatement (Second) Conflict of Laws § 2. See also Dodge at 2079 (identifying recognition/enforcement of foreign judgments as adjudicative comity operating as a principle of recognition).

${ }^{59}$ Unlike interstate judgments that receive full faith and credit, foreign judgments do not. For more information on international attempts to create a multinational treaty on judgment recognition and enforcement, see e.g., Justyna Regan, Recognition and Enforcement of Foreign Judgments - A Second Attempt in the Hague?, 14 Rich. J. Global L. \& Bus. 63 (2015); Yuliya Zeynalova, The Law on Recognition and Enforcement of Foreign Judgements: Is It Broken and How Do We Fix It?, 31 BERKELEY J. INT'L L. 150 (2013).

${ }^{60}$ Restatement (Third) Foreign Relations Law $\S 481$ and 482.

${ }^{61}$ Restatement (Third) Foreign Relations Law $\S 482$.

${ }^{62}$ Restatement (Third) Foreign Relations Law $\S 482$.

${ }^{63}$ Restatement (Third) Foreign Relations Law $§ 482$. 


\section{Cases Involving Foreign Affairs Doctrines}

The fourth type of cases that considers foreign law are cases involving foreign affairs doctrines. ${ }^{64}$ The Animal Science case fits nicely in this category because the defendant cited three examples of foreign affairs doctrines as reasons to set aside its liability for violating U.S. antitrust law: the Act of State Doctrine; the Foreign Sovereign Compulsion Doctrine; and a defense of international comity (in general). ${ }^{65}$ To support (and oppose) these defenses, both parties in the Animal Science litigation produced documentation on Chinese law. The doctrine of international comity is discussed in detail above; the sections below focus on the other two foreign affairs doctrines asserted in the Animal Science case.

\section{a. Act of State Doctrine}

The Act of State doctrine prohibits U.S. federal courts from questioning the validity of an official act of a foreign sovereign performed within its own territory. ${ }^{66}$ According to the U.S. Supreme Court, "[e]very sovereign state is bound to respect the independence of every other sovereign state...Redress of grievances by reason of such acts must be obtained through the means open to be availed by sovereign powers as between themselves." 67

In practice, the Act of State defense depends not only on valid reasons why diplomatic channels of dispute resolution are more appropriate than adjudication in U.S. federal court, but also on proof of an official public act. ${ }^{68}$ Proof of an official public act requires submission of a "statute, decree, order or resolution" of the foreign sovereign. ${ }^{69}$ The official public act requirement, therefore, prompted the defendants in the Animal Science case (and the Chinese government in its amicus briefs) to provide documentation and analysis of Chinese law, which remains stacked in the records, figuratively speaking.

\section{b. Foreign Sovereign Compulsion Doctrine}

The foreign sovereign compulsion doctrine restrains U.S. federal courts from imposing liability for committing violations of U.S. law abroad if those violations were compelled by the law(s) of the relevant foreign jurisdiction. ${ }^{70}$ It is the "devil made me do it" defense, focused on fairness to the defendant rather than on notions of sovereignty. ${ }^{71}$ As explained by the lower court in the Animal Science case:

${ }^{64}$ See Anthony J. Colangelo, Absolute Conflicts of Law, 91 IND. L.J. 719, 729-30 (2016) (noting that cases involving foreign affairs doctrines can blur into and be confused with conflicts cases involving jurisdiction).

${ }^{65}$ See In re Vitamin C Antitrust Litigation, 837 F.3d 175, 184 (2016) (performing a comity analysis with ten enumerated factors to decide whether to exercise jurisdiction). See also Dodge at 2079 and 2101-06 (saying both of these defenses are examples of prescriptive comity, with act of state operating from a principle of recognition and foreign sovereign compulsion operating from a principle of restraint).

${ }^{66}$ See Underhill v. Hernandez, 168 U.S. 250, 252 (1897) ("[e]very sovereign state is bound to respect the independence of every other sovereign state and the courts of one country will not sit in judgment on the acts of the government of another done within its own territory.") See also Banco Nacional de Cuba v. Sabbatino, 376 U.S. 398, 401 (1964) (finding that the act of state doctrine "precludes the courts of this country from inquiring into the validity of the public acts a recognized foreign sovereign power committed within its own territory."); Dodge at 2101-2 (arguing that act of state is an example of prescriptive comity operating as a principle of recognition). But see Thomas Schultz \& Niccolò Ridi, Comity and International Courts and Tribunals, 50 CORNELl INT'L L.J. 577, 584 (2017) (identifying the act of state doctrine as operating as a principle of restraint).

${ }^{67}$ Underhill v. Hernandez, 168 U.S. 250, 252 (1897).

68 See Restatement (Third) of Foreign Relations Law $\S 443$.

${ }^{69}$ See Restatement (Third) of Foreign Relations Law $\S 443$. See also Alfred Dunhill of London Inc. v. Republic of Cuba, 425 U.S. 682 (1976) (holding that arguments dependent on the act of state doctrine require proof of a "statute, decree, order or resolution").

${ }^{70}$ See Restatement (Third) of Foreign Relations Law $\S \S 441-2$ (explaining that proponents of the foreign sovereign compulsion defense must prove not only a foreign government act but also that such an act entailed compulsion). See also GEORGE A. Berman, Transnational Litigation in a Nutshell, (2003) (noting that courts are aware that parties invoking the foreign sovereign compulsion doctrine may have "courted" the compulsion); Dodge at 2104-5 (identifies the foreign compulsion doctrine as prescriptive comity operating as a principle of restraint).

${ }^{71}$ See In re Vitamin C Antitrust Litigation, 584 F.Supp.2d 546, 551 (2008) (contrasting the foreign sovereign compulsion doctrine from the act of state doctrine) (reversed on other grounds). 
"[t]he defense of foreign sovereign compulsion...focuses on the plight of a defendant who is subject to conflicting legal obligations under two sovereign states. Rather than being concerned with diplomatic implications of condemning another country's official acts, the foreign sovereign compulsion doctrine recognizes that a defendant trying to do business under conflicting legal regimes may be caught between the proverbial rock and a hard place where compliance with one country's laws results in violation of another's."72

Naturally, the proponent of this defense must produce comprehensive documentation on the law(s) of the relevant foreign jurisdiction that identifies a direct conflict with U.S. law and demonstrates the forced nature of compliance with foreign law. ${ }^{73}$ The opposing party will likewise produce documentation and analysis of the foreign sovereign's law to contest the conflict and/or the compulsion. The defendants in Animal Science submitted official Chinese legislation and analysis to show that they were obligated by China to fix prices on their products, in direct violation of U.S. antitrust laws. In response, plaintiffs scoured China's official and unofficial positions to cast genuine doubt on whether China compelled defendants to violate U.S. laws throughout the entirety of the relevant time frame.

Regardless of whether challenges to jurisdiction are ultimately successful, parties submit foreign law during litigation and that documentation remains in the record for the benefit of future researchers (if they can find it).

\section{Cases Involving Federal Statutes that Implicate Foreign Law}

Several federal statutes explicitly incorporate foreign law by reference. The Foreign Corrupt Practices Act (FCPA), for example, creates civil and criminal penalties for bribing foreign officials but recognizes an affirmative defense based on foreign law. ${ }^{74}$ It states that a defendant can escape liability if "the payment, gift, offer or promise of anything of value that was made, was lawful under the written laws and regulations of the foreign official's, political party's, party official's, or candidate's country..."75 By its terms, this affirmative defense allows defendants to produce foreign law that exculpates them from liability.

Similarly, Congress explicitly created an exception to Title VII of the 1964 Civil Rights Act that allows workplaces located in foreign countries to discriminate against their workers "if compliance [with Title VII] would cause such an employer...to violate the law of the foreign country in which such workplace is located." "76 Employers accused of discrimination need only point to a foreign law in conflict with Title VII protections.

Another example is a federal statute called the Lacey Act Amendments of 1981, which imposes civil and criminal penalties for the importation, exportation, transport, sale, receipt, acquisition, or purchase in interstate or foreign commerce of "any fish or wildlife taken, possessed, transported, or sold in violation of...any foreign law." 77 The Tariff Act of 1930 is another example that forbids the importation of wild animals and birds in violation of foreign law. ${ }^{78}$ By their terms, these federal statutes require plaintiffs (or prosecutors) to survey foreign law to succeed on their claims.

Moreover, several federal statutes implicate foreign materials as relevant for a claim or defense. For example, our U.S. patent laws encourage harmonization with the patent laws of other countries and, therefore, parties will produce foreign patent laws in U.S. patent litigation. ${ }^{79}$ Also, the federal tax code permits tax breaks

${ }^{72}$ In re Vitamin C Antitrust Litigation, 584 F.Supp.2d 546, 551 (2008) (reversed on other grounds).

${ }^{73}$ See Restatement (Third) of Foreign Relations Law $\S \S 441-2$ (explaining that proponents of the foreign sovereign compulsion defense must prove not only a foreign government act but also that such an act entailed compulsion). See also Anthony J. Colangelo, Absolute Conflicts of Law, 91 IND. L.J. 719, 730 (2016) (“'[u]nder this doctrine, courts will (sometimes) not apply U.S. law prohibiting a party's foreign activity if the party shows that the conduct was actually compelled by foreign law and not just encouraged or approved."); George A. Berman, Transnational Litigation in a Nutshell, (2003) (noting that courts are aware that parties invoking the foreign sovereign compulsion doctrine may have "courted" the compulsion).

${ }_{74}^{74}$ Pub. L. 95-213 (Dec. 19, 1977), as codified in 15 USC $\S 78 \mathrm{dd}-1$ through $\S 78 \mathrm{dd}-3$.

7515 USC $\S 78 \mathrm{dd}-1(\mathrm{c})(1) ; 15$ USC $\S 78 \mathrm{dd}-2(\mathrm{c})(1) ; 15$ USC $\S 78 \mathrm{dd}-3(\mathrm{c})(1)$.

7642 U.S.C. $\S 2000 \mathrm{e}-1(\mathrm{~b})$.

7716 USC $\S 3372$ (2)(A). See also § 2(B) re: plants.

7819 USC $\S 1527$.

${ }^{79}$ E.g., Rotec Industries, Inc. v. Mitsubishi Corp, 215 F.3d 1246 (2000) (looking to foreign law to construe the definition of "infringement" under U.S. patent law). See also, Timothy R. Holbrook, Should Foreign Patent Law Matter?, 34 CAmPBell L. REV. 581, 584-5 (2012) (explaining that U.S. courts look to foreign law as persuasive support in patent litigation in part because the US signed the TRIPS agreement and the purpose of TRIPS was to harmonize patent law). 
for citizens paying foreign taxes; by implication, to receive a tax credit, one must produce documentation of foreign tax payments. ${ }^{80}$ Furthermore, as noted by the lower court in the Animal Science case, the Sherman Act, which prohibits "every contract, combination in the form of trust or otherwise, or conspiracy, in restraint of trade or commerce among the several States, or with foreign nations," 81 was intended by Congress to apply "to foreign conduct that was meant to produce and did in fact produce some substantial effect in the United States." ${ }^{2}$ Lastly, our immigration statutes require foreign documentation and evidence of foreign law to prove eligibility to remain in the United States. ${ }^{83}$

\section{Cases Interpreting Treaties Ratified by the U.S.}

Treaties ratified by the U.S. have the force of U.S. federal law, ${ }^{84}$ but require judges to look beyond U.S. domestic law in their interpretation. ${ }^{85}$ The U.S. Supreme Court has explained that the interpretation of treaties begins with the text and expands to include the travaux preparatoires and the interpretations of the treaty by other signatory states..$^{86}$

For example, in Abbott v. Abbott, litigants asked the U.S. Supreme Court to construe the phrase "right of custody" as provided in the Hague Convention on the Civil Aspects of International Child Abduction, a treaty ratified by the U.S. and implemented into federal law in 1988. ${ }^{87}$ As part of its analysis, the litigants produced (and the Court reviewed) documentation and analysis of Chilean law to determine if the plaintiff's scope of parental authority in the child's country of habitual residence constituted "rights of custody" under the treaty. ${ }^{88}$ In addition to Chilean law, the parties also submitted (and the Court construed) case law from "sister signatories" to the treaty, which the Court deemed "entitled to considerable weight." 89

\section{Cases Alleging Violations of Customary International Law}

U.S. federal courts also receive party submissions about foreign law in cases involving claims for relief under customary international law. For example, the Alien Tort Claims Act (ATCA, which is also called the Alien Tort Statute, or ATS) is an example of a federal statute that gives subject matter jurisdiction to U.S. federal courts to adjudicate claims for tort injuries "committed in violation of the law of nations." 90 The ATCA does not, itself, provide a cause of action; it is merely a jurisdictional statute. ${ }^{91}$ Yet, it is a vehicle that drives causes of action based on violations of customary international law, such as allegations of piracy and torture, into U.S. federal court. To succeed on the

${ }^{80} 26$ USC $\S 901$.

8115 USC $\S 1$.

82 In re Vitamin C Antitrust Litigation, 837 F.3d 175, 184 (2016).

${ }^{83}$ For example, proof of foreign marriages and births rely on foreign government documents. Also, asylum seekers produce evidence of foreign government law and policy to meet their burdens of establishing a credible fear of persecution under 8 U.S. C. $\S 1158(B)(i)$ and 8 U.S.C. $\S 1101(a)(42)(A)$.

${ }^{84}$ See U.S.C.A. Const. Art. VI cl. 2.

${ }^{85}$ See e.g., Medellin v. Texas, 552 U.S. 491, 507 (2008) (“'b]ecause a treaty ratified by the United States 'is an agreement among sovereign powers,' we have also considered as 'aids to its interpretation' the negotiating and drafting history of the treaty as well as 'the post-ratification understanding' of signatory nations.").

${ }^{86}$ See e.g., Medellin v. Texas, 552 U.S. 491, 507 (2008) (“[b]ecause a treaty ratified by the United States 'is an agreement among sovereign powers,' we have also considered as 'aids to its interpretation' the negotiating and drafting history of the treaty as well as 'the post-ratification understanding' of signatory nations.").

${ }^{87}$ Hague Convention on the Civil Aspects of International Child Abduction (Convention), Oct. 24, 1980, T.I.A.S. No. 11670, S. Treaty Doc. No. 99-11, https:/www.hcch.net/en/instruments/conventions/status-table/?cid=24. See also International Child Abduction Remedies Act), 102 Stat. 437, 22 USC $\S 9001$ et seq. (implementing the treaty into the U.S. legal framework).

${ }^{88}$ Abbott v. Abbott, 560 U.S. 1, 10-15 (2010).

${ }^{89}$ Abbott at 16-18 (analyzing case law from Israel, the United Kingdom, Austria, South Africa, Germany, Canada, and France).

9028 USC 1350. See also Kiobel v. Royal Dutch Petroleum, Co., 569 U.S. 108, 114 (tracing the history and use of the Act but eliminating courts' ability to recognize torts committed outside the United States).

${ }^{91}$ See Sosa v. Alvarez-Machain, 542 U.S. 724 (2004) (recognizing private claims of international law violations under the common law). 
merits of a cause of action based on customary international law, plaintiffs must produce both foreign and international legal materials to demonstrate the prohibition of defendants' conduct by the law of nations.

\section{Controversial Cases}

The final category of U.S. federal court cases that consider foreign law is the only controversial one of this taxonomy. This category includes all situations in which litigants (and judges) cite foreign law as persuasive support in arguments construing the U.S. Constitution or other U.S. domestic law that does not explicitly implicate or refer to foreign law. ${ }^{92}$ For example, the U.S. Supreme Court cited foreign law as persuasive support in holding that the Eighth Amendment of the U.S. Constitution prohibited capital punishment for minors ${ }^{93}$ and that the Due Process Clause permitted the right to engage in same sex intimate relations. ${ }^{94}$ These cases sparked a debate among Justices, academics, and politicians who accused the Justices who joined the majority opinion of subverting the democratic process and "cherry picking" legal support. ${ }^{95}$ Yet, zealous advocacy looks to all forms of support and litigants will likely continue to cite foreign law when it bolsters their arguments.

\section{Rule 44.1 of the Federal Rules of Civil Procedure (FRCP)}

When civil litigants in federal district courts assert that their case involves an issue or question involving foreign law, they must provide notice and documentation, as required by the Federal Rules of Civil Procedure (FRCP) Rule 44.1. ${ }^{96}$ As explained in Part IV of this Article, FRCP Rule 44.1 is a key to locating the rich reserves of foreign legal materials buried in federal case dockets. Section A, below, traces the development of FRCP Rule 44.1; section B analyzes its inconsistent application in U.S. federal courts.

\section{A. The Development of FRCP Rule 44.1}

In the Animal Science case, during oral argument, counsel for the American purchasers explained that ... "courts in this country have been interpreting and construing foreign law for two centuries and not outsourcing that task to other entities simply because those questions are difficult." 97 Until FRCP Rule 44.1, however, federal courts lacked a consistent procedure for considering cases involving foreign law.

\section{Foreign Law in Federal Courts prior to 1938}

Prior to the creation of the FRCP Rule 44.1,98 the U.S. legal system followed the English common law rule that characterized the law of a foreign country as a question of "fact." 99 In practice, this "fact theory" required parties

92 Much has been written about this controversy. See e.g., Robert J. Delahunty \& John Yoo, Against Foreign Law, 29 Harv. J. L. \& Pub. PoL'y 291 (2005) (outlining reasons to reject review of foreign law in adjudicating claims under the U.S. Constitution); Diarmuid F. O'Scannlain, What Role Should Foreign Practice and Precedent Play in the Interpretation of Domestic Law, 80 Notre Dame L. Rev. 1893 (2005) (giving the perspective of a federal court judge); Thomas O. Main, The Word Commons and Foreign Laws, 46 CORNELl INT'L L.J. 219, 248-50 (2013) (drawing the distinction between criticisms of reviewing foreign law for constitutional adjudication from the everyday occurrence of reviewing foreign law in the other types of cases included in this taxonomy); Eugene Volokh, Foreign Law in American Courts, 66 OKLA. L. Rev. 219, 220-3 (2014) (showing the negative and practical impact of state legislature attempts to ban all review of foreign law in state courts).

93 See Roper v. Simmons, 543 U.S. 551 (2005).

94 See Lawrence v. Texas, 539 US 558, 578 (2003).

95 See e.g., Transcript of Discussion between U.S. Supreme Court Justices Antonin Scalia and Stephan Breyer at American University Washington College of Law (Jan. 13, 2005), transcript available at http://www.freerepublic.com/focus/news/ 1352357/posts, video available at https:/www.c-span.org/video/?185122-1/constitutional-relevance-foreign-court-decisions (transcribing Justice Scalia's criticism that use of foreign law is like looking for your friends at a cocktail party).

96 FED. R. Civ. P. 44.1.

97 Animal Science v. Hebei, No. 16-1220, Transcript (Apr. 24, 2018), p. 7.

${ }^{98}$ FED. R. Civ. P. See also infra Part II.B.3.

99 See Talbot v. Seeman, 1 Cranch 1, 38 (1801) (holding that foreign law is not binding on U.S. courts, cannot be "officially take[n] notice of," and "must be proved as facts"). See also Arthur R. Miller, Federal Rule 44.1 and the "Fact" Approach to 
to plead and prove foreign law in their claims or defenses as they would any other fact. ${ }^{100}$ Parties intending to rely on foreign law had to provide significant detail ${ }^{101}$ about the content and impact of the foreign law at the initial pleading stage, which was sometimes too early in the genesis of a case to identify the applicability of foreign law at all. ${ }^{102}$ Additionally, parties had to follow strict rules of evidence in submitting proof of foreign law. For example, parties relying on written foreign law had to provide authentic, official versions of the foreign law from an authorized agent of the foreign government. ${ }^{103}$ Secondary sources were excluded as hearsay. ${ }^{104}$ Expert testimony was appropriate only when the foreign law was unwritten or when the official version of the written law was unavailable. ${ }^{105} \mathrm{In}$ such situations, parties had to identify experts who could appear in-person to orally communicate the content of the foreign law during direct- and cross-examination. ${ }^{106}$

Federal courts struggled to identify the body - judge or jury - responsible for ascertaining foreign law. ${ }^{107}$ Usually, juries decided questions of fact, but some judges felt compelled to seize control of foreign law decisions, especially when parties relied on written materials. ${ }^{108}$ The body responsible for ascertaining the content of foreign law, whether jury or judge, could only rely on the evidence presented ${ }^{109}$ and its interpretations of foreign law lacked

Determining Foreign Law: Death Knell for a Die-Hard Doctrine, 65 Mich. L. Rev. 613, 618-9 (1967) (describing U.S. courts' embrace of the English common law rule as "blind obedience" performed "without re-examination"); Ernest G. Lorenzen, Story's Commentaries on the Conflict of Laws - One Hundred Years After, 48 Harv. L. Rev. 15, 26 (1934) (crediting Joseph Story's early observation of "the established doctrine of Anglo-American law" that requires parties to prove foreign law as a fact); Arthur Nussbaum, The Problem of Proving Foreign Law, 50 Y ALE L.J. 1018, 1018 (1941) (clarifying that treating foreign law as fact was not initially limited to England, but that England continued to embrace the concept long after the civil law jurisdictions abandoned it); GEEROMS at 73-4 (noting that England still maintains a strict common law approach and characterizes foreign law as "fact"); Gregory S. Alexander, Application and Avoidance of Foreign Law in the Law of Conflicts, 70 Nw. U. L. Rev. 602, 606 (1976) (giving the theoretical justification that the forum was only capable of knowing/applying its own law and everything else had to be treated as a fact to be proved).

${ }^{100}$ See Arthur Nussbaum, The Problem of Proving Foreign Law, 50 YALE L.J. 1018, 1018 (1941) (tracing the "fact theory" back to the eighteenth century).

${ }^{101}$ See Arthur R. Miller, Federal Rule 44.1 and the "Fact" Approach to Determine Foreign Law: Death Knell for a DieHard Doctrine, 65 Мich. L. Rev. 613, 638-9 (defining the amount of information needed in the formal pleading as somewhere between a full disclosure and "reasonably specific abstract" with "detailed allegations.").

${ }^{102}$ See Arthur R. Miller, Federal Rule 44.1 and the "Fact" Approach to Determine Foreign Law: Death Knell for a DieHard Doctrine, 65 Мich. L. Rev. 613, 643-4 (equating the pleading stage with the "embryonic stage of the litigation" when attorneys do not yet have mastery of their cases).

${ }^{103}$ See Arthur Nussbaum, The Problem of Proving Foreign Law, 50 YALE L.J. 1018, 1026 (citing as "unreasonable" demands by U.S. courts that parties provide official editions of foreign legislation, even though official editions may not exist and despite the reality that practitioners in those civil law jurisdictions rely on unofficial versions from private collections).

${ }^{104}$ See id.

${ }^{105}$ See Arthur R. Miller, Federal Rule 44.1 and the "Fact" Approach to Determine Foreign Law: Death Knell for a DieHard Doctrine, 65 Mich. L. Rev. 613, 621-2 (saying oral testimony could come in as a deviation in instances when authentic copies of foreign law were unavailable).

${ }^{106}$ See Arthur Nussbaum, The Problem of Proving Foreign Law, 50 YALE L.J. 1018, 1025 (1941) (comparing the difficulty of finding an expert in the U.S., where experts in civil law were few and concentrated in metropolitan centers, versus finding an expert in England, a country geographically surrounded by experts in civil law).

${ }^{107}$ See Arthur R. Miller, Federal Rule 44.1 and the "Fact" Approach to Determine Foreign Law: Death Knell for a DieHard Doctrine, 65 Mich. L. Rev. 613, 650-1 (explaining that judges refused inherent power to take judicial notice of foreign law, but did carve out rare exceptions based on "rudimentary principles" in situations of a defendant's "gross antisocial behavior"). See also Frederick J. De Sloovére, The Functions of Judge and Jury in the Interpretation of Statutes, 46 HARV. L. REV. 1086, 1104-5 (1933) (agreeing with Dean Wigmore, Joseph Story, and other scholars of the era that a question involving interpretation of a written, foreign statute should go to the judge as "[i]t is hardly necessary to point out the absurdity of turning over to a jury questions of foreign law when questions of domestic law are deemed too complicated for them").

${ }^{108}$ See Arthur R. Miller, Death Knell, p. 682 (citing dictum from a U.S. Supreme Court case that provided "[a]lthough the law of a foreign jurisdiction may be proved as a fact...statutes and decisions having been proved or otherwise properly brought to the attention of the court, it may itself deduce from them an opinion as to what the law of the foreign jurisdiction is....").

${ }^{109}$ See Arthur R. Miller, Death Knell, 620-1 (explaining that courts conducted no independent investigations of foreign law as they wouldn't any other fact). 
confidence ${ }^{110}$ as well as the force of stare decisis. ${ }^{111}$ Appellate courts varied in the standard of review they applied to findings of foreign law. ${ }^{112}$

Parties struggled to produce sufficient evidence of foreign law under shifting expectations. ${ }^{113}$ Failure to prove foreign law usually led to application of the law of the forum. ${ }^{114}$ Courts justified turning to the forum law when faced with inadequate proof of foreign law by creating presumptions. ${ }^{115}$ When parties failed to plead foreign law, courts presumed they implicitly agreed to apply forum law instead ${ }^{116}$ or courts presumed that the law of the forum was the same as the foreign law. ${ }^{117}$ These presumptions continue today, ${ }^{118}$ despite criticism. ${ }^{119}$

\section{Foreign Law in Federal Courts between 1938-1966}

In 1934, Congress authorized the U.S. Supreme Court to create general rules of civil procedure for federal district courts. ${ }^{120}$ On December 20, 1937, the U.S. Supreme Court adopted the FRCP ${ }^{121}$ and, after transmission to Congress, ${ }^{122}$ the FRCP finally became effective on September 16, 1938. ${ }^{123}$

${ }^{110}$ See e.g., Wood \& Selick, Inc. v. Compagnie Generale Transatlantique, 43 F.2d 941, 943 (2d Cir. 1930) ("The embarrassment is...that we have to interpret another system of law according to notions wholly foreign to it').

${ }^{111}$ See John G. Sprankling \& George R. Lanyi, Foreign Law in American Courts, 19 StAn. J. INT'L L. 3, 63 (1983) (explaining that foreign law interpretations had no precedential effect in the era before FRCP Rule 44.1 because, in part, courts wrongly assumed that cases involving foreign law were rare).

112 See 9A Wright \& Miller, Fed. Prac. \& Proc. Civ. $§ 2446$ (citing appellate decisions that fully reviewed questions of foreign law and others that applied the "clearly erroneous" standard reserved for questions of fact).

113 See Arthur Nussbaum, The Problem of Proving Foreign Law, 50 YALE L.J. 1018, 1029 (1941) (listing the costs of obtaining, preparing, and relocating an expert among the various economic penalties parties endured to prove foreign law). See also Arthur R. Miller, Federal Rule 44.1 and the "Fact" Approach to Determine Foreign Law: Death Knell for a DieHard Doctrine, 65 Мich. L. Rev. 613, 617 (describing the process of establishing foreign law in the common law era as "torturous" and "frustrating" for the bench).

114 See Arthur Nussbaum, The Problem of Proving Foreign Law, 50 Yale L.J. 1018, 1035 (1941) (citing the Cuba Railroad v. Crosby case, where the U.S. Supreme Court dismissed Plaintiff's action for failure to prove foreign law, as an example of a rare (and, in Nussbaum's view, unfair) outcome). See also Miller at 639 saying that the court may dismiss the complaint with leave to replead.

115 See Gregory S. Alexander, Application and Avoidance of Foreign Law in the Law of Conflicts, 70 Nw. U. L. REV. 602 (1976) (labeling these presumptions as "legal fictions," "guises," and "procedural devices" that make it easier for the court to do what it really wants to do: apply the law it is trained to apply: forum law).

${ }^{116}$ But see Arthur Nussbaum, The Problem of Proving Foreign Law, 50 YALE L.J. 1018, 1039-40 (1941) (distinguishing silent acquiescence to the application of forum law from a stipulation involving a contract with a forum selection clause that points to the law of a foreign country).

117 See Arthur Nussbaum, The Problem of Proving Foreign Law, 50 YALE L.J. 1018, 1037 (1941) (clarifying that U.S. courts only applied the presumption when the foreign law was the law of a common law jurisdiction). See also Rudolf B. Schlesinger, The Effect of Failure to Invoke or Prove the Applicable Foreign Law, 59 CoRnELL L. REv. 1, 7-8 (1973) (finding that courts applied the presumption when the foreign country was in the common-law orbit or when the point at issue was a fundamental concept presumably shared by most nations). See also Arthur R. Miller, Federal Rule 44.1 and the "Fact" Approach to Determine Foreign Law: Death Knell for a Die-Hard Doctrine, 65 MicH. L. REv. 613,635 (explaining that this presumption was the most frequently invoked).

${ }^{118}$ See 9A Wright \& Miller, Fed. Prac. \& Proc. Civ. $\$ 2443$ (3d ed. Apr. 2018 Supp.) (“[i]f a party fails to give sufficient notice, the court is not obligated to apply the relevant foreign law and ordinarily will apply the forum's law, either by assuming that foreign law has been waived or that foreign and forum law are the same").

119 See e.g., Arthur Nussbaum, The Problem of Proving Foreign Law, 50 YAle L.J. 1018, 1038 (1941) (calling any presumption that equated forum law with foreign law as "naïve" and "so unrealistic that it offends common sense").

120 Act of June 19, 1934, ch. 651, 48 Stat. 1064.

${ }^{121}$ Fed. R. Civ. P.; see also, Federal Rules of Civil Procedure, in Black's LaW Dictionary (10th ed. 2014). [also need cite that US Supreme Court adopted them].

122 Transmitted to Congress by the Attorney General on January 3, 1938 (Cong. Rec. vol 83, part 1, p. 13, Exec. Comm. 905; H. Doc 460 abd G, Dic 588, 75th Cong.).

123308 U.S. 645. 
In many ways, the FRCP achieved its purpose of unifying federal procedural rules, but it did not alter federal practice for parties and courts facing cases involving foreign law. ${ }^{124}$ The FRCP retained the common law rules that characterized foreign law as "fact." Additionally, courts continued to force parties to raise issues of foreign law at the pleadings stage and prove the content of foreign law through official texts and expert (oral) testimony. ${ }^{125}$ The ascertainment of foreign law, as a determination of fact, was still supposed to go to the jury and it survived challenge unless it was "clearly erroneous." 126

In 1958, the American Bar Association lobbied Congress to reform judicial procedures for raising and proving foreign law. ${ }^{127}$ Congress established the Commission and Advisory Committee on International Rules of Judicial Procedure ("the Commission"). ${ }^{128}$ The Commission, working in collaboration with other advocacy groups, completely revamped the FRCP. ${ }^{129}$ The changes became effective July $1,1966 .{ }^{130}$

\section{Foreign Law in Federal Courts 1966-present}

FRCP Rule 44.1 was created as part of the 1966 revision of the FRCP to "furnish Federal courts with a uniform and effective procedure for raising and determining an issue concerning the law of a foreign country."131 FRCP Rule 44.1 provides:

A party who intends to raise an issue about a foreign country's law must give notice by a pleading or other writing. In determining foreign law, the court may consider any relevant material or source, including testimony, whether or not submitted by a party or admissible under the Federal Rules of Evidence. The court's determination must be treated as a ruling on a question of law. ${ }^{132}$ [emphasis mine]

\section{a) Notice}

The first sentence of FRCP Rule 44.1 requires parties to give the court (and opposing counsel) written notice of an issue involving the law of a foreign country, ${ }^{133}$ however, such notice is no longer limited to the pleadings. ${ }^{134}$ Under FRCP Rule 44.1, parties may now take their time to fully research and analyze their cases to determine

${ }^{124}$ See 9A Wright \& Miller, Fed. Prac. \& Proc. Civ. $§ 2441$ (3d ed. Apr. 2018 Supp.) (confirming that the subject of raising and determining foreign law was not directly addressed in the FRCP until the creation of FRCP Rule 44.1 in 1966).

125 See Wright \& Miller, Federal Practice \& Procedure $§ 1253$ (3d ed. Supp. Apr. 2018) (finding courts’ refusal to abandon the "fact" pleading in cases involving foreign law "surprising" given FRCP Rule 8(a)'s liberal approach to pleading).

${ }^{126}$ But see Arthur R. Miller, Federal Rule 44.1 and the "Fact" Approach to Determining Foreign Law: Death Knell for a Die-Hard Doctrine, 65 Mich. L. Rev. 613, 683-4 (1967) (citing First and Fifth Circuit precedent that held the jury was not an appropriate tribunal for the ascertainment of foreign law).

${ }^{127}$ See Arthur R. Miller, Federal Rule 44.1 and the "Fact" Approach to Determining Foreign Law: Death Knell for a DieHard Doctrine, 65 Mich. L. Rev. 613, 615 (1967) (attributing the increasing number of cases involving foreign law to the expansion of international trade and commerce following World War II). See Arthur R. Miller, Federal Rule 44.1 and the "Fact" Approach to Determining Foreign Law: Death Knell for a Die-Hard Doctrine, 65 Mich. L. Rev. 613, 631 (1967) (using the term "schizoid" to characterize federal practice after the Siegelman case).

128 Act of Sept. 2, 1958, 72 Stat. 1743.

129 The groups included the Advisory Committee on Civil Rules of the Judicial Conference of the United States, the National Conference of Commissioners on Uniform State Laws, and the Columbia Law School Project on International Procedure.

${ }^{130}$ FED. R. Civ. P.

131 Advisory Committee Notes, Fed. R. Civ. P. 44.1 (1966).

${ }^{132}$ Fed. R. Civ. P. 44.1. The original text of FRCP Rule 44.1 did not specifically exempt application of the Federal Rules of Evidence, but that language was added in 1972 to clarify the court's expansive freedom in considering material. See also 9A Wright \& Miller, Fed. Prac. \& Proc. Civ. § 2445 (3d ed. Apr. 2018 Supp.) (noting that FRCP Rule 44.1 is identical to several Uniform laws adopted by states for guiding the process of raising and determining foreign law in state courts); Peter Hay chapter (pp. 421-7) (providing a chart that lists the U.S. state courts that enacted state procedural rules that mirror FRCP Rule 44.1).

${ }^{133}$ Fed. R. Civ. P. 44.1. See also Advisory Committee Notes (explaining that the intent of the first sentence is to "avoid unfair surprise").

${ }^{134}$ Fed. R. Civ. P. 44.1. See also Advisory Committee Notes ("It may, but need not be, incorporated in the pleadings"). 
whether or not foreign law is both relevant and beneficial to their cause. ${ }^{135}$ The Advisory Committee Notes accompanying FRCP Rule 44.1 recommend a standard of "reasonableness" to challenges of untimely notice. ${ }^{136}$

The rule is silent on the depth of detail required in the notice, but the Advisory Committee recommends that the notice "should specify the segment of the controversy thought to be governed by foreign law and identify the country whose law is claimed to control the matter." 137 A party that fails to provide reasonable notice forfeits the ability to rely on foreign law. ${ }^{138}$

\section{b) Any Relevant Material or Source}

Unlike under the common law, where parties had to follow the rules of (best) evidence and fact-finders couldn't look beyond the record, FRCP Rule 44.1 permits the court to consider "any relevant material or source." 139 According to the Advisory Committee Notes accompanying FRCP Rule 44.1, the phrase "any relevant material" implies that the court "is not limited by material presented by the parties; it may engage in its own research and consider any relevant material thus found." 140 Parties may submit any material, as long as it is relevant, without needing to satisfy evidence formalities. ${ }^{141}$ In the Advisory Committee's view, FRCP 44.1 is founded on the assumption that the manner in which law is provided to the judge is a procedural issue, not an evidentiary one, and, therefore, the rules of evidence do not apply when educating the judge about foreign law. ${ }^{142}$ FRCP Rule 44.1 permits ${ }^{143}$ courts to "take an active role in the process of ascertaining foreign law....[t]hus, a judicial practice of automatically refusing to engage in research or to assist or to provide direction for counsel with regard to what is wanted by the court to help it establish the content of the applicable foreign law would be inconsistent with one of the rule's basic premises"144 Yet, FRCP Rule 44.1 does not expect judges to become experts in foreign law, as they are experts in domestic law,

${ }^{135}$ See Advisory Committee Notes ("A requirement that notice of foreign law be given only through the medium of the pleadings would tend in the latter instances to force the party to engage in a peculiarly burdensome type of investigation which might turn out to be unnecessary; and correspondingly, the adversary would be forced into a possible wasteful investigation").

${ }^{136}$ Advisory Committee Notes ("The stage which the case has reached at the time of the notice, the reason proffered by the party for his failure to give earlier notice, and the importance to the case as a whole of the issue of foreign law sought to be raised, are among the factors which the court should consider in deciding a question of the reasonableness of notice"). See also 9A Wright \& Miller, Fed. Prac. \& Proc. Civ. § 2443 (3d ed. Apr. 2018 Supp.) (“"ww]ritten notice at trial may be reasonable if the issue was not apparent until then. However, in the absence of extenuating circumstances, a party should not be permitted to raise an issue of foreign law after the final pretrial conference described in FRCP Rule 16 has been held").

${ }^{137}$ Advisory Committee Notes, Fed. R. Civ. P. 44.1.

${ }^{138}$ See Roger M. Michalski, Pleading and Proving Foreign Law in the Age of Plausibility Pleading, 59 BufF. L. Rev. 1207, 1220 (2011) (referencing the presumption that "courts interpret lack of reasonable notice as a waiver of a 'foreign law argument' or as implied consent to an application of local law)."

139 Fed. R. Civ. P. 44.1.

${ }^{140}$ Fed. R. Civ. P. 44.1, Advisory Committee Notes. See also Arthur R. Miller, Death Knell, p. 660 (“All too often counsel will do an inadequate job of researching and presenting foreign law or will attempt to prove alien law in such a partisan fashion that the court is obliged to go beyond their offerings. On occasion, the trial judge will have better foreign-law resources than counsel, or, because of his personal background or prior exposure to a particular country's law, have greater expertise in researching and applying foreign law than the attorneys").

${ }^{141}$ But see John R. Brown, 44.1 Ways to Prove Foreign Law, 9 MAr. Law. 179, 185 (1984) (noting that a judge has discretion to waive evidentiary rules, but need not do so).

${ }^{142}$ See Schmertz at 701-4 (citing the Advisory Committee's Note and noting that even though FRCP 44.1 doesn't adhere to evidence guidelines, a court could request substantial compliance with Rules of Evidence 706 \& 902).

${ }^{143}$ See Arthur R. Miller, Federal Rule 44.1 and the "Fact" Approach to Determining Foreign Law: Death Knell for a DieHard Doctrine, 65 Mich. L. REv. 613, 661 (characterizing the determination of foreign law as a "co-operative venture" among parties and the court). GEEROMS at 123 (saying Rule 44.1 "only creates additional responsibilities for the judge, [it] does not affect the existing practice according to which parties have to adduce information on the applicable foreign law").

144 9A Wright \& Miller, Fed. Prac. \& Proc. § 2444 (3d ed. Apr. 2018 Supp.). But see George T. Yates III, Foreign Law before Domestic Tribunals, 18 Va. J. Int'l L. 725, 728-9, 748 (1978) (comparing the approaches to foreign law among the world's judges and finding that U.S. federal judges are neither fully active nor fully passive, but rather take an intermediary position where they have discretion to raise and investigate foreign law issues without the obligation). See also John R. Brown, 44.1 Ways to Prove Foreign Law, 9 MAR. LAw. 179, 183-4 (1984) (defining the passive approach as the approach taken in the traditional common law era where the judge mak8es the parties plead and prove foreign law; the active approach as 
and thus, the rule does not force judges to take judicial notice of foreign law or determine foreign law without assistance of counsel. ${ }^{145}$

\section{c) Question of Law}

The third sentence of FRCP Rule 44.1 officially identifies foreign law as a question of law - not fact - and in so doing entitles determinations of foreign law to a de novo standard of review. ${ }^{146}$ Although FRCP Rule 44.1 does not explicitly delegate determinations of foreign law to judge or jury, the Advisory Committee Notes accompanying FRCP Rule 44.1 say "[i]t has long been thought, however, that the jury is not the appropriate body to determine issues of foreign law." 147

\section{B. The Application of FRCP Rule 44.1}

Under FRCP Rule 44.1, foreign law is law and not a fact to be proven as other facts under the evidence rules, ${ }^{148}$ but foreign law also requires notice and demonstration, ${ }^{149}$ unlike domestic law. ${ }^{150}$ Scholars who have noted the unique treatment of foreign law under FRCP Rule 44.1 have labelled foreign law a "tertium genus," a hybrid category existing between law and fact. ${ }^{151}$

So, the parties must provide some documentation of foreign law, but FRCP Rule 44.1 doesn't specify how much. Worse yet, FRCP Rule 44.1 fails to articulate a division of labor between the court and the parties. ${ }^{152}$ Who court or litigant(s) - has the ultimate responsibility of figuring out what the content of the foreign law is? ${ }^{153}$ Federal

the approach taken by judges in civil law countries where they are required to raise and investigate issues of foreign law; and the discretionary approach as the approach taken by FRCP Rule 44.1).

${ }^{145}$ See Fed. R. Civ. P. 44.1, Advisory Committee Notes (stating that judicial notice "would put an extreme burden on the court in many cases."). See also Rudolf B. Schlesinger, Recurrent Problem in Transnational Litigation: The Effect of Failure to Invoke or Prove the Applicable Foreign Law, 59 Cornell L. Rev. 1, 19-20 (1973) (explaining that FRCP Rule 44.1 does not dictate the consequences of a party's failure to prove foreign law because of concern that such regulation would exceed the U.S. Supreme Court's rule-making power under the Enabling Act).

${ }^{146}$ Fed. R. Civ. P. 44.1, Advisory Committee Notes. But see Andrew S. Pollis, Comment to Blog Post, Civ. P. \& Fed. CTs. BLOG (Sept. 28, 2016), http:/lawprofessors.typepad.com/civpro/2016/09/ninth-circuit-decision-on-frcp-441-foreign-law-theuniform-recognition-act.html ("Even if the standard of review is technically de novo, there is no question that an appellate court defers to the trial court's evaluation of the experts' opinions; what choice does it have?)."

${ }^{147}$ Fed. R. Civ. P. 44.1, Advisory Committee Notes.

${ }^{148}$ Fed. R. Civ. P. 44.1. See also Miller (calling Rule 44.1's reclassification of foreign law as a question of law as marking a "death knell to the fact theory").

${ }^{149}$ Fed. R. Civ. P. 44.1.

${ }^{150}$ See Stephen L. Sass, Foreign Law in Federal Courts, 29 Aм. J. Comp. L. 97,98 (1981) (noting that judges are required to take judicial notice of domestic law). Philip D. Stacey, Rule 44.1., Bodum USA v. La Cafetiere, and The Challenge of Determining Foreign Law, 6 Seventh CiR. Rev. 472, 476-7 (2011) (finding that experts are not called to construe domestic law, but are explicitly embraced to construe foreign law in FRCP Rule 44.1).

${ }^{151}$ See Stephen L. Sass, Foreign Law in Federal Courts, 29 Aм. J. Comp. L. 97, 98 (1981). But see Roger J. Miner, The Reception of Foreign Law in U.S. Federal Courts, 43 Aм. J. Comp. L. 581, 584 (1995) (disagreeing with Sass's tertium genus theory and viewing decisions of foreign law as solely those of law). See also R. Schlesinger, A Recurrent Problem in Transnational Litigation: The Effect of Failure to Invoke or Prove the Applicable Foreign Law, 59 CORNell L. REv. 1, 3 (1973) (proposing to write a new theory on foreign law as neither fact nor law).

${ }^{152}$ See Roger M. Michalski, Pleading and Proving Foreign Law in the Age of Plausibility Pleading, 59 Buff. L. Rev. 1207, 1232 (2011). (Claiming that a lack of a division of labor leads to a lack of predictability in the way courts handle foreign law from complete reliance on party pleadings on the one hand to utter disregard for party pleadings on the other).

${ }^{153}$ See Peter D. Trooboff, Proving Foreign Law, NAT'L L.J. (Sept. 18, 2006) ("Enactment of Rule 44.1 did not fully resolve the issues of how to determine the content of foreign law"). See also Gregory S. Alexander, Application and Avoidance of Foreign Law in the Law of Conflicts, 70 Nw. U. L. Rev. 602, 608 (1976) (explaining that FRCP Rule 44.1 ended the confusion over which body decides foreign law (the judge) and the standard of review of that body's decision (de novo) but that FRCP Rule 44.1 did not eliminate the burden on the parties to discover and demonstrate foreign law). 
circuits disagree. ${ }^{154}$ Some courts place the full responsibility on the parties. If the parties do not provide "sufficient proof" of foreign law, the court will default to the law of the forum. ${ }^{155}$ These courts follow a strict "adversarial tradition." 156 Other courts, however, assume some, if not all, of the responsibility of determining the content of foreign law. If the parties provide insufficient or conflicting documentation, the court will conduct independent research or utilize other available methods until it exposes the "correct" content of the foreign law. ${ }^{157}$ These courts follow a "court-centered tradition." 158 The path a court chooses results in application of different law (foreign or forum) and, therefore, significantly impacts case outcomes. ${ }^{159}$

The sections below focus on these two competing approaches to litigation involving foreign law because they highlight what one scholar refers to as the "conceptual incoherence" of FRCP Rule 44.1 in permitting both approaches to coexist. ${ }^{160}$ The U.S. Supreme Court's decision in the Animal Science case did not address or resolve the federal circuit split on the issue of FRCP Rule 44.1's failure to identify the proper division of labor in determining the content of foreign law. As a result, the current state of the law is best summarized by the Ninth Circuit, which said "we are uncertain [who] bears the burden of establishing the content of foreign law[.]"161

\section{The Common Ground}

Regardless of how a federal circuit answers the ultimate responsibility question under FRCP Rule 44.1, litigants provide documentation on foreign law using methods they also use for domestic law. ${ }^{162}$ U.S. litigants accurately assume that the vast majority of judges do not have any knowledge of foreign law or legal systems, so they try to produce as much credible information as possible. ${ }^{163}$

${ }^{154}$ See Matthew J. Ahn, 44.1 Luftballons: The Communication Breakdown of Foreign Law in the Federal Courts, 89 N.Y. U. L. REV. 1343, 1347-8 (2014). (Focusing on the burden standards of FRCP Rule 44.1 across circuits and arguing that FRCP Rule 44.1 should be amended to separate cases that hinge on a foreign statute from those that do not).

155 See John G. Sprankling \& George R. Lanyi, Pleading and Proof of Foreign Law in American Courts, 19 Stan. J. InT'L L. 3, 9-10 (1983) (arguing that judges' preference for forum law is not due to malice or laziness, but rather to practical concerns about costs, time, and party preferences). See also Ahn article at 1369-70 (linking the inappropriate "burden of proof" language relied on by some federal courts in FRCP Rule 44.1 cases to misinterpretation of the Restatement (Second) Conflict of Laws) 9A Wright \& Miller, Fed. Prac. \& Proc. Civ. § 2441 (3d ed. Apr. 2018 Supp.) (shaming any judge that forces a burden of proof on the parties to evade her own judicial responsibility under FRCP Rule 44.1).

${ }^{156}$ See Roger M. Michalski, Pleading and Proving Foreign Law in the Age of Plausibility Pleading, 59 BuFF. L. REV. 1207, 1261-2 (2011) (explaining that under the adversarial model, the parties are "presumed to be the masters of their own fate").

157 Infra.

${ }^{158}$ See Roger M. Michalski, Pleading and Proving Foreign Law in the Age of Plausibility Pleading, 59 BuFF. L. REv. 1207, 1207-8 (2011) (explaining that under the court centered model, the court supplants the agency of the parties to find and apply the right law).

159 Ahn at 1372 ("The effect that this uncertainty has on litigants should be obvious: Perhaps based only on the panel of judges you will be assigned on appeal several years in the future, the amount of information you have to provide at, or even before, trial might vary wildly").

${ }^{160}$ See Roger M. Michalski, Pleading and Proving Foreign Law in the Age of Plausibility Pleading, 59 BuFF. L. REV. 1207, 1215-6 (2011) (claiming that the U.S.'s failure to choose between an adversarial approach and a court-centered approach to structuring the pleading of foreign law has led to the worst of both worlds).

${ }^{161}$ Tobar v. U.S., 639 F.3d 1191, 1200 ( $9^{\text {th }}$ Cir. 2011).

162 See Matthew J. Wilson, Improving the Process: Transnational Litigation and the Application of Private Foreign Law in U.S. Courts, 45 N.Y.U. J. INT'L L. \& PoL. 1111, 1127-9 (2013) (“[i]n practice, foreign law is typically argued and briefed like domestic law”). See also Carolyn B. Lamm \& K. Elizabeth Tang, Rule 44.1 and Proof of Foreign Law in Federal Court, 30 Litig. 31, 31 (2003) ("'s]ince the adoption of Rule 44.1, federal courts approach proof of foreign law in much the same way they approach proof of applicable domestic law").

163 See Thomas O. Main, The Word Commons and Foreign Laws, 46 Cornell InT'L L.J. 219, 253-6 (2013) (noting that "American legal education does not systematically equip judges or lawyers to carry out research in a foreign legal system"). See also Stephen L. Sass, Foreign Law in Federal Courts, 29 Am. J. Comp. L. 97 109-110 (1981). (“Ascertainment and interpretation of foreign law, other than the laws of the English-speaking world, require linguistic and juridical skills possessed by very few judges"); John G. Sprankling \& George R. Lanyi, Pleading and Proof of Foreign Law in American Courts, 19 STAN. J. InT'L L. 3, 9-10 (1983) ("Common-law judges and lawyers frequently have difficulty understanding legal systems other than their own"). 


\section{a. Primary Sources of Foreign Law (translated into English)}

Naturally, the best method of demonstrating foreign law is to provide the court with copies of primary sources of law including: constitutions, codes, legislation, regulations, judicial decisions, and administrative materials. ${ }^{164}$ English translations of foreign law do not need to be official or certified, ${ }^{165}$ but many advocates will opt for certified translations whenever client resources allow. ${ }^{166}$ Certified or not, however, the quality of translations vary, leading one scholar to say it is "virtually impossible to translate literally...because not only the words, but the form of expression...often have no corresponding words or ideas among English-speaking people."167

\section{b. Expert Affidavits/Declarations}

In practice, once an attorney knows her case involves foreign law, she will seek an expert in that foreign jurisdiction. ${ }^{168}$ The job of the expert is to (i) help litigants gather relevant primary sources of foreign law (see above) and (ii) write an affidavit (also called a declaration) that explains how the foreign law is construed and applied in the foreign jurisdiction. ${ }^{169}$ Finding a capable, credible expert remains a huge challenge for litigants. ${ }^{170}$

${ }^{164}$ See Carolyn B. Lamm \& K. Elizabeth Tang, Rule 44.1 and Proof of Foreign Law in Federal Court, 30 LiTig. 31,33 (2003) ("[t]he best practice is to submit a foreign legal opinion supported by official sources of foreign law (e.g., publications in the country's official gazette), including authenticated copies of foreign law if possible. Statutes in foreign languages present the twofold complication of requiring translation and explication, but a court could hardly refuse a translation approved by the government that promulgated the law in the first place"). See also Matthew J. Wilson, Improving the Process: Transnational Litigation and the Application of Private Foreign Law in U.S. Courts, 45 N.Y.U. J. INT'L L. \& Pol. 1111, 1127-9 (2013). (noting that foreign legal materials do not need to be sworn, verified, or presented in any specific form but courts will respond more favorably to objective and verified submissions).

165 Fed. R. Civ. P. 44.1, infra.

166 See Carolyn B. Lamm \& K. Elizabeth Tang, Rule 44.1 and Proof of Foreign Law in Federal Court, 30 LiTig. 31 , 35 (2003) ("[o]btain translations of the foreign law you plan to use in their entirety. It will not do to submit or translate only those portions of the law to be relied on and face the charge that language was taken out of context. If an official English translation is available from a ministry of the foreign government, so much the better. If there is none, find a reputable, well-credentialed translator").

${ }^{167}$ Philip D. Stacey, Rule 44.1., Bodum USA v. La Cafetiere, and The Challenge of Determining Foreign Law, 6 SEVENTH CIR. Rev. 472, 492 (2011) (quoting Fritz Moses, International Legal Practice (1939) and claiming that translation issues are still just as prevalent today). See also id. at 491-2 (citing, as an example, the French word contrat, which covers what Americans call "conveyances" or "trusts," but does not cover what Americans label contracts).

168 See Arthur R. Miller, Death Knell, pp. 658-9 (explaining that although a foreign law expert is not required, federal courts expect it and failure to produce it might damage a litigant's case). See also Thomas F. Bridgman, Proof of Foreign Law and Facts, 45 J. AIR L. \& CoM. 845, 859 (1980) (explaining that there is no reason to delay obtaining expert testimony once foreign law becomes an issue in the case); Louise Ellen Teitz, From the Courthouse in Tobago to the Internet: The Increasing Need to Prove Foreign Law in US Courts, 34 J. MAR. L. \& Com. 97, 107 (2003). ("[i]ndeed, it is the exception for a court to apply foreign law without the use of some expert testimony").

169 See Matthew J. Wilson, Improving the Process: Transnational Litigation and the Application of Private Foreign Law in U.S. Courts, 45 N.Y.U. J. INT'L L. \& Pol. 1111, 1127-9 (2013). (explaining that litigants enlist experts to provide valuable insight into the meaning, weight, and relevance of each proffered source of foreign law and also to explain nuance that is not obvious from the text of the materials themselves). See also Christopher A. Whytock \& Marcus S. Quintanilla, The New Multipolarity in Transnational Litigation: Foreign Courts, Foreign Judgments, and Foreign Law, 18 Sw. J. INT'L L. 31, 445 (2011) (agreeing that a foreign expert is essential for understanding foreign law in context); John Henry Merryman, Foreign Law as a Problem, 19 STAN. J. INT'L L. 151, 154 (1983) (experts “perform two related but fundamentally distinguishable functions: expert witness and expert consultant. They may submit affidavits to the court, appear to testify, or both. They will also be consulted from time to time by counsel in developing the strategy and tactics of the case"); Stephen A. Saltzburg, Discovering and Applying Foreign and International Law in Domestic Tribunals: An Introduction to the Second Annual Sokol Colloquium, 18 VA. J. INT'L L. 609, 616-7 (1978) (arguing that trial lawyers who rely on foreign experts to prepare materials on foreign law should be held to the same ethical standards in confirming accuracy as they are held in domestic law cases).

${ }^{170}$ See John Henry Merryman, Foreign Law as a Problem, 19 StAn. J. InT'L L. 151, 170 (1983) (requesting a directory of experts on foreign law). See also GEEROMS at 143 (noting that all American authors mentioned the difficulty of finding qualified experts and stating that a proposal by the New York Bar to compile a list of foreign law experts never came to fruition). As a cautionary tale, see Philip D. Stacey, Rule 44.1., Bodum USA v. La Cafetiere, and The Challenge of Determining Foreign Law, 6 
As one scholar from the print era noted: "they are not listed in the yellow pages." 171 And in the Internet age, despite a plethora of claims of expertise online, few people have what it takes to empower a judge to comfortably construe foreign law. ${ }^{172}$ The best experts will perform a "double process of translation" wherein they analyze terms and concepts embedded within the culture of the foreign legal system and then explain those terms and concepts within the context of the U.S. legal framework. ${ }^{173}$ Needless to say, this process requires fluency in both the foreign legal system and the U.S. legal system plus impeccable language and communication skills. ${ }^{174}$ Many litigants will not be able to afford the substantial costs involved with identifying and hiring a foreign law expert. ${ }^{175}$

\section{The Divide}

Litigants often do not agree on whether or not foreign law applies at all. ${ }^{176}$ Moreover, even when parties stipulate that the law of a foreign jurisdiction applies, they do not necessarily agree on which section/case/regulation applies or which party's expert provides the more accurate explanation of the foreign law. ${ }^{177}$ In fact, some litigants purposely overwhelm the court with confusing and conflicting accounts of foreign law as a strategy to encourage the court to apply forum law instead of foreign law. ${ }^{178}$ Since FRCP Rule 44.1 fails to identify the actor - court or party who is ultimately responsible for determining the content of foreign law, federal circuits will approach cases that involve confusing and conflicting accounts of foreign law, differently. ${ }^{179}$

SEventh CiR. Rev. 472, 481, n. 63 (2011) (citing language from a court that named and shamed a "prominent Spanish attorney and former law professor" who failed to cite any cases or legal authority in his declaration of Spanish law).

${ }^{171}$ John Henry Merryman, Foreign Law as a Problem, 19 Stan. J. Int'L L. 151, 155-6 (1983). But see Hans W. Baade, Proving Foreign and International Law in Domestic Tribunals, 18 VA. J. INT'L L. 619, 624 (1978) (saying foreign counsel is readily available thanks to modern technologies).

${ }^{172}$ See Matthew J. Wilson, Improving the Process: Transnational Litigation and the Application of Private Foreign Law in U.S. Courts, 45 N.Y.U. J. INT'L L. \& PoL. 1111, 1127-9 (2013) (explaining that there are no formal qualifications for expert witnesses testifying about foreign law). See also John G. Sprankling \& George R. Lanyi, Foreign Law in American Courts, 19 StAN. J. INT'L L. 3, 45 (1983) ("The qualifications of experts vary greatly. At one extreme are experts so clearly qualified that rejection of them as expert witnesses would constitute reversible error. An expert who studied law in the appropriate jurisdiction, practiced the relevant specialty there, and is sufficiently familiar with U.S. law and the English language to interpret the foreign law in terms meaningful to Americans probably fit this class. At the opposite extreme, there are also "experts" whose qualifications are nearly nonexistent").

${ }^{173}$ See John Henry Merryman, Foreign Law as a Problem, 19 StAn. J. InT'L L. 151, 155-6 (1983) (favoring experts trained thoroughly in local law over experts trained solely in foreign law). See also John G. Sprankling \& George R. Lanyi, Foreign Law in American Courts, 19 StAN. J. INT'L L. 3, 43 (1983) (explaining that experts, acting as consultants and witnesses, must not only understand and synthesize the foreign law, they must then compare and explain it to an American audience).

${ }^{174}$ See John Henry Merryman, Foreign Law as a Problem, 19 Stan. J. InT'L L. 151, 155-6 (1983) (identifying a "double process of translation" that the best foreign law experts perform in the context of litigation).

${ }^{175}$ See John Henry Merryman, Foreign Law as a Problem, 19 STAn. J. InT’L L. 151, 156 (1983) (warning that the substantial costs associated with use of foreign law experts can lead to unequal justice since the wealthier party can afford to "buy" the better expert).

${ }^{176}$ See John G. Sprankling \& George R. Lanyi, Pleading and Proof of Foreign Law in American Courts, 19 STAn. J. Int'L L. 3, 9-10 (1983) (identifying the varied strategic reasons litigants may have for avoiding foreign law).

${ }^{177}$ See Matthew J. Wilson, Improving the Process: Transnational Litigation and the Application of Private Foreign Law in U.S. Courts, 45 N.Y.U. J. INT'L L. \& Pol. 1111, 1134 (2013) (noting that a court, in an effort to streamline the process, may force litigants to identify the aspects of foreign law on which they can agree).

${ }^{178}$ See Matthew J. Wilson, Demystifying the Determination of Foreign Law in U.S. Courts: Opening the Door to a Greater Global Understanding, 46 WAKE FoREST L. REv. 887, 911 (2011) ("Even if the law is relatively simple and straightforward, a litigant may attempt to paint a picture of confusion by seeking out an expert that will directly contradict the foreign law as explained by the opposing party").

${ }^{179}$ See Roger M. Michalski, Pleading and Proving Foreign Law in the Age of Plausibility Pleading, 59 Buff. L. Rev. 1207, 1207-8 (2011) (identifying the two distinct traditions underlying the U.S. model for determining the content of foreign law: the adversarial tradition and the court-centered tradition). 


\section{a. The Strict Adversarial Approach}

Courts that follow the strict adversarial approach believe that the party asserting the applicability of foreign law is responsible for demonstrating what the content of the foreign law is. ${ }^{180}$ These courts dismiss any notion that $U$. S. judges have an inherent, all-encompassing legal expertise that somehow makes up for a lack of education and resources. ${ }^{181}$ As one scholar argues: [U.S. judges] "are experts in American law... To reason that a judge can determine the law of a foreign country because judges are 'experts on law'....is tantamount to reasoning that a cardiologist can fix an ACL tear in the knee because doctors are experts in medicine, a rather suspect proposition." 182

Additionally, courts that follow a strict adversary approach rarely conduct independent research to educate themselves on the content of foreign law. ${ }^{183}$ These courts assert that the Advisory Committee grants the freedom to "engage in [their] own research," but does not obligate them to do so. ${ }^{184}$ In the words of one federal judge: "[s]ome of you will be thinking that Rule 44.1 expressly authorizes the Court to do independent research into foreign law. Yes, it does - but it doesn't require it to. Trial judges usually can't. Indeed, they usually shouldn't. And they probably won't...We have quite a few things to do besides decoding the Codigo Civil..."185

Almost every court, regardless of inclination, will apply forum law when parties fail to raise or provide any documentation of foreign law. ${ }^{186}$ After all, FRCP Rule 44.1 requires some party-based effort. ${ }^{187}$ But some courts are predisposed to avoid foreign law entirely, even when a choice-of-law analysis requires its application; these courts insert a "burden of proof" requirement on the parties similar to that which existed pre-FRCP Rule 44.1 when foreign

180 See e.g., Milton Pollack, Proof of Foreign Law, 26 Aм. J. ComP. L. 470, 470 (1978) (recommending that parties brief and argue foreign law as thoroughly as they do domestic law because FRCP Rule 44.1 did not magically gift judges with knowledge of foreign law and, thus, did not end a party's burden to demonstrate "what the law of a foreign country is"). But see 9A Wright \& Miller, Fed. Prac. \& Proc. Civ. $\$ 2441$ (3d ed. Apr. 2018 Supp.) (finding fault with any court that ignores its duties to determine the content of foreign law once notice has been given).

${ }^{181}$ See Matthew J. Wilson, Demystifying the Determination of Foreign Law in U.S. Courts: Opening the Door to a Greater Global Understanding, 46 WAKE Forest L. REV. 887, 897-9 (2011) (remarking that U.S. judges receive limited training in foreign law and legal research). See also Philip D. Stacey, Rule 44.1., Bodum USA v. La Cafetiere, and The Challenge of Determining Foreign Law, 6 SEventh CIR. REv. 472, 497 (2011) (criticizing the elitist approach taken by Judges Easterbrook and Posner in the Bodum case).

182 Philip D. Stacey, Rule 44.1., Bodum USA v. La Cafetiere, and The Challenge of Determining Foreign Law, 6 SEVENTH Cir. Rev. 472, 494 (2011).

${ }^{183}$ See Arthur R. Miller, Death Knell, p. 660 (“"[n]othing in the Rule requires him to engage in private research...The Rule recognizes that judges are reluctant to research and determine foreign law without some assistance from the attorneys and does not obligate them to undertake that burden"). See also Stephen L. Sass, Foreign Law in Federal Courts, 29 Am. J. ComP. L. 97 109-110 (1981) (finding only three cases, decided by the same district court, where the court supplemented party presentation of foreign law with its own research).

184 Carey v. Bahama Cruise Lines, 864 F.2d 201, 205 (1st Cir. 1988).

185 Milton Pollack, Proof of Foreign Law, 26 AM. J. Comp. L. 470, 471 (1978) (recommending parties strive for a "full exposition" of foreign law so as to avoid the negative consequences associated with a failure to prove foreign law). See also Matthew J. Wilson, Demystifying the Determination of Foreign Law in U.S. Courts: Opening the Door to a Greater Global Understanding, 46 WAKE FOREST L. REV. 887, 928-9 (2011) (noting that despite an ability to do so, few courts appoint neutral foreign law experts because the process of identifying those experts and the contours of their duties requires a lot of judicial effort); Comm. Int'l Com. Disputes, Proof of Foreign Law after Four Decades with Rule 44.1 FRCP and CPLR 4511, 61 THE RECORD 49, 54 (2006) (questioning whether appointment of a neutral expert undermines the adversary system).

186 See Thomas O. Main, The Word Commons and Foreign Laws, 46 CoRnELl INT'L L.J. 219, 274-5 (2013) (confirming that judges "simply refuse to consider foreign law if the parties have not raised it or have not assisted the court in ascertaining its content"). See also Stephen L. Sass, Foreign Law in Federal Courts, 29 Aм. J. Comp. L. 97 109-110 (1981) (citing two appellate court decisions that used presumptions to apply forum law when parties failed to invoke or make any effort to prove foreign law).

${ }^{187}$ John G. Sprankling \& George R. Lanyi, Foreign Law in American Courts, 19 STAN. J. InT’L L. 3, 80 (1983) (stating that a party unwilling to make at least some effort to establish foreign law has in effect acquiesced in the use of domestic law). See also Papastrati v. Papasakelariou, 43 FlA. L. WeEkly D902, 2018 WL 1936508 (Fla. Dist. Ct. App., Apr. 25, 2018) (“[w]e affirm without further discussion and write only to point out the perilous journey undertaken by counsel when they ask the trial court to interpret an order of a foreign jurisdiction without providing the court a proper foundation for interpretation of that order"). 
law was a fact to be proven. ${ }^{188}$ In the view of these courts, parties must "prove" foreign law and failure to do so leads to application of forum law. ${ }^{189}$ Courts within the Third and Fifth Circuits are most notorious for choosing this path, both at trial and on review. ${ }^{190}$ Scholars have attacked these circuits for misinterpreting and misapplying FRCP Rule 44.1, ${ }^{191}$ but until the Supreme Court rules otherwise, the "burden of proof" requirement is still precedent in these circuits.

\section{b. The Court-Centered Approach}

As stated above, few U.S. courts will apply foreign law when parties fail to raise or produce any documentation of foreign law, ${ }^{192}$ but the division between courts that follow the strict adversarial tradition and courts that follow the court-centered tradition occurs when parties do raise an issue of foreign law and do produce some documentation of foreign law. ${ }^{193}$ Unlike courts that follow the strict adversarial approach, courts that follow the courtcentered approach will seek other means of information about foreign law outside of the party presentations, until they are confident of applying the "correct" law. ${ }^{194}$

Judges that follow a court-centered approach view themselves, primarily, as experts in law, skilled in legal analysis and application. They focus on the similarities of foreign law and domestic law, rather than the differences. They are not intimidated by foreign legal systems or worry that they are outsiders incapable of looking-in. A federal judge from New York in the 1970s explained:

"In any event, though we view another country's law but through a glass darkly, I am less pessimistic than Justice Holmes as to our ability to handle foreign legal authorities. Of course, arguing foreign law is more complex than when the law is domestic. More of the steps must be spelled out, more assumptions made

188 See 9A Wright \& Miller, Fed. Prac. \& Proc. Civ. § 2441 (3d ed. Apr. 2018 Supp.) (“"[a]ny language in decisions that appear to determine the content of foreign law based on the proponents' failure of proof ignores that the duty rests with the judges to determine foreign law once notice has been given...").

189 See Louise Ellen Teitz, From the Courthouse in Tobago to the Internet: The Increasing Need to Prove Foreign Law in US Courts, 34 J. MAR. L. \& CoM. 97, 101 (2003) (showing that many courts will apply forum law in situations of insufficient proof of foreign law based on presumptions that existed when foreign law was a fact to be proved). See also Louise Ellen Teitz, Determining and Applying Foreign Law: The Increasing Need for Cross-Border Cooperation, 45 N.Y.U. J. INT'L L. \& Pol. 1081,1093 (2013) (arguing that courts that default to forum law in the absence of "sufficient proof" of foreign law misconstrue FRCP Rule 44.1).

${ }^{190}$ Matthew J. Ahn, 44.1 Luftballons: The Communication Breakdown of Foreign Law in the Federal Courts, 89 N.Y. U. L. Rev. 1343, 1369-70 (2014) (noting that Third Circuit was the first court to adopt the "burden of proof" language and the Fifth Circuit relied on outdated precedent to do the same).

191 See Ahn article at 1367 n. 121 (ridiculing the Fifth Circuit's Banque Libanaise case for finding insufficient proof of foreign law and defaulting to forum law even though the parties produced several secondary sources, extensive translations of the relevant law, and a letter from an expert on foreign law). See also 9A Wright \& Miller, Fed. Prac. \& Proc. Civ. $\S$ 2441 (3d ed. Apr. 2018 Supp.) (stating that judicial reliance on a proof standard in FRCP Rule 44.1 cases ignores judicial duty under FRCP Rule 44.1).

${ }^{192}$ See e.g., Stephen L. Sass, Foreign Law in Federal Courts, 29 Aм. J. Comp. L. 97 109-110 (1981) (finding that American courts expect counsel to undertake the basic responsibility for research in domestic cases and that the expectation is reasonably increased in cases considering foreign law). See also Thomas O. Main, The Word Commons and Foreign Laws, 46 CoRNELL INT'L L.J. 219, 274-5 (2013) ([m]ost judges "simply refuse to consider foreign law if the parties have not raised it or have not assisted the court in ascertaining its content"); John G. Sprankling \& George R. Lanyi, Foreign Law in American Courts, 19 StAn. J. INT'L L. 3, 80 (1983) (citing the general rule that, with few exceptions, courts are willing to conduct independent research only after the parties demonstrate some good faith effort); GEROMS at 41-2 (comparing and contrasting American judges and their civil law counterparts on the power and willingness to raise issues of foreign law sua sponte).

193 See Roger M. Michalski, Pleading and Proving Foreign Law in the Age of Plausibility Pleading, 59 BuFF. L. REv. 1207, 1261-2 (2011) (explaining that the strict adversarial approach places all the responsibility for raising and proving foreign law on the parties whereas the court centered approach places the responsibility for finding and applying the right law on the court).

${ }^{194}$ See, e.g. Roger J. Miner, The Reception of Foreign Law in the U.S. Federal Courts, 43 Am. J. ComP. L. 581,584 (1995) ("[b]ecause I have this view [that foreign law is solely an issue of law], I think that it becomes the duty of the court to find and apply the relevant foreign law as soon as it becomes apparent to the court that foreign law governs."). See also Roger M. Michalski, Pleading and Proving Foreign Law in the Age of Plausibility Pleading, 59 BufF. L. REv. 1207, 1207-8 (2011) (noting the consistency and predictability that the court-centered tradition values). 
explicit, less taken for granted. Yet, if what is relied on is law and not some primitive religion or the whim of a tyrant, the form of reasoning will be familiar." 195

Courts that follow the court-centered tradition reject any notion of a proof standard within FRCP Rule 44.1. ${ }^{196}$ These courts believe that if a court is unsure of the content of foreign law, the court has an obligation to cure the problem by looking beyond party presentations until it discovers the "correct" law to apply. ${ }^{197}$ As Wright and Miller recognize: "[i]t simply is not fair to bar a party from recovering when neither his attorney nor the court is able to conjure up the content of the governing law." 198

Courts that follow a court-centered tradition employ a number of strategies to cure uncertainty stemming from unclear, conflicting, or in any other way, inadequate party presentations. ${ }^{199}$ For example, the Seventh Circuit insists that both trial and appellate courts must research the content of foreign law independently. ${ }^{200}$ In Bodum USA, Inc. v. La Cafetiere, Inc., a three-member panel of the Seventh Circuit, which included Chief Judge Easterbrook, Judge Posner, and Judge Wood, delved into French contract law to decide a trademark infringement case. ${ }^{201}$ Each of the Seventh Circuit judges agreed on the judgment, but wrote his/her own separate opinion on judicial responsibility in determining the content of foreign law under FRCP Rule 44.1.

In the majority opinion, Chief Judge Easterbrook criticized lower courts' reliance on biased expert declarations and said that judges should instead favor "unbiased" written secondary sources on a foreign jurisdiction's law:

"[i]t is no more necessary to resort to expert declarations about the law of France than about the law of Louisiana ....Trying to establish foreign law through experts' declarations not only is expensive (experts must be located and paid) but also adds an adversary's spin, which the court must then discount. Published sources such as treatises do not have the slant that characterizes the warring declarations presented in this case. Because objective, English-language descriptions of French law are readily available, we prefer them to the parties' declarations."202

195 Milton Pollack, Proof of Foreign Law, 26 Am. J. Comp. L. 470, 474 (1978). See also Matthew J. Wilson, Improving the Process: Transnational Litigation and the Application of Private Foreign Law in U.S. Courts, 45 N.Y.U. J. INT'L L. \& Pol. 1111,1147 (2013) ("[n]ot only are federal and state courts capable of applying the law of other sovereigns, but they have also done so for well over a century").

196 See 9A Wright \& Miller, Fed. Prac. \& Proc. Civ. § 2441 (3d ed. Apr. 2018 Supp.) (“[a]ny language in decisions that appear to determine the content of foreign law based on the proponents' failure of proof ignores that the duty rests with the judges to determine foreign law once notice has been given...").

${ }^{197}$ See e.g., Roger J. Miner, The Reception of Foreign Law in the U.S. Federal Courts, 43 Aм. J. CoMP. L. 581,583 (1995) ("[m]y own view of the matter is that a court has the affirmative obligation to seek out the applicable foreign law whether the parties have established that law or not"). See also Aurora Bewicke, The Court's Duty to Conduct Independent Research into Chinese Law: A Look at Federal Rule of Civil Procedure 44.1 and beyond, 1 CHINESE L. \& PoL'y REv. 97, 106 (2005) (pointing out that scholars think FRCP Rule 44.1 should push judges to take a more affirmative duty to conduct research on foreign law or else request a full presentation by the parties). Louise Ellen Teitz, From the Courthouse in Tobago to the Internet: The Increasing Need to Prove Foreign Law in US Courts, 34 J. MAR. L. \& Com. 97, 118 (2003) (saying that FRCP Rule 44.1 makes clear that foreign law is an issue of law and therefore judges are not justified in defaulting to forum law when foreign law governs); Edwin P. Carpenter, Presumptions as to Foreign Law: How They are Affected by Federal Rule of Civil Procedure 44.1, 10 WASHBURN L.J. 296 (1970) (finding that federal judges have not released common law "inhibitions" even after the adoption of FRCP Rule 44.1).

198 9A Wright \& Miller, Fed. Prac. \& Proc. Civ. § 2447 (3d ed. Apr. 2018 Supp.).

199 See e.g., Twohy v. First National Bank of Chicago, 758 F.2d 1185, 1193-4 (7th Cir. 1985) (chiding the district court for not requesting a "full presentation" of foreign law by the parties).

${ }^{200}$ See Twohy v. First National Bank of Chicago, 758 F.2d 1185, 1193 (7th Cir. 1985)(“[i]n determining...questions of law [under Rule 44.1], both trial and appellate courts are urged to research and analyze foreign law independently..."). See also Kalm"ich v. Bruno, 553 F.2d 549, 552 (7th Cir. 1977) (reversing district court's interpretation of Yugoslavian statute on the basis of its own independent research and analysis); Louise Ellen Teitz, Determining and Applying Foreign Law: The Increasing Need for Cross-Border Cooperation, 45 N.Y.U. J. INT'L L. \& PoL. 1081, 1090 (2013 (referring to the Seventh Circuit's consistent message over the last 25 years that courts at the district and appellate levels have a responsibility to determine the correct foreign law).

${ }^{201} 621$ F.3d 624 (7th Cir. 2010).

202 Bodum at 628-9. But see Philip D. Stacey, Rule 44.1., Bodum USA v. La Cafetiere, and The Challenge of Determining Foreign Law, 6 SEVEnTH CIR. REV. 472, 497 (2011) (criticizing Easterbook's assumption that the law functions as it is written). 
In his concurrence, Judge Posner wanted "to amplify" the court's criticism of expert declarations and to encourage independent judicial research. ${ }^{203} \mathrm{He}$ wrote:

“...our [American] linguistic provincialism does not excuse intellectual provincialism. It does not justify our judges in relying on paid witnesses to spoon feed them foreign law that can be found well explained in English-language treatises and articles. I do not criticize the district court in this case, because he was following the common practice. But it is a bad practice... It is excusable only when the foreign law is the law of a country with such an obscure or poorly developed legal system that there are no secondary materials to which the judge could turn." 204

Judge Wood concurred with the judgment, but wrote separately to defend use of experts in determining the content of foreign law:

"Rule 44.1 itself establishes no hierarchy for sources of foreign law, and I am unpersuaded by my colleagues' assertion that expert testimony is categorically inferior to published, English-language materials... There will be many times when testimony from an acknowledged expert in foreign law will be helpful, or even necessary, to ensure that the U.S. judge is not confronted with a "false friend" or that the U.S. judge understands the full context of the foreign provision. Some published articles or treatises, written particularly for a U.S. audience, might perform the same service, but many will not...It will often be most efficient and useful for the judge to have before her an expert who can provide the needed precision on the spot, rather than have the judge wade through a number of secondary sources. In practice, the experts produced by the parties are often the authors of the leading treatises and scholarly articles in the foreign country anyway...205

The three separate opinions in the Bodum case represent the nuanced views of courts that follow a court-centered tradition on cases involving foreign law under FRCP Rule 44.1. Although suspicious of bias, these courts accept expert declarations and translations of foreign law materials, but are willing to conduct independent judicial research to find and apply the "correct" law.

\section{Creating a Reference Source that Extracts Foreign Law from Civil Pleadings Filed in U.S. Federal Courts: A Prototype}

As explained above, litigants (and judges) need to find and construe foreign law in a variety of situations, yet they have difficulty identifying credible foreign law experts and gathering sufficient documentation of foreign law content. Certainly, existing legal research databases, when accessible to litigants (and judges), provide some relief. Westlaw and Lexis provide selected foreign law content from English-speaking countries as well as law reviews or

See also Roger J. Miner, The Reception of Foreign Law in U.S. Federal Courts, 43 Am. J. Comp. L. 581, 588 (1995) (denying that experts are automatically suspect just because they are hired by the parties).

${ }^{203}$ Bodum at 631. See also John Henry Merryman, Foreign Law as a Problem, 19 STAN. J. INT'L L. 151, 157 (1983). (outlining internal and external pressures that make experts inherently partisan). But see Frederick Gaston Hall, Not Everything is as Easy as a French Press: The Dangerous Reasoning of the Seventh Circuit on Proof of Foreign Law and a Possible Solution, 43 Geo. J. InT'L L. 1457, 1472 (2012) (rejecting Judge Posner's argument that judges are experts in law without use of foreign law experts who are able to explain cultural and legal differences to combat implicit assumptions).

204 Bodum 633-4. See also John Henry Merryman, Foreign Law as a Problem, 19 Stan. J. InT'L L. 151, 157-8 (1983) (explaining that it is human nature for an expert to become biased even without an intention to do so). But see Philip D. Stacey, Rule 44.1., Bodum USA v. La Cafetiere, and The Challenge of Determining Foreign Law, 6 SEVENTH CIR. Rev. 472, 490 (2011) (rejecting Easterbrook's and Posner's standard that requires judges to rely more on written secondary sources than expert testimony). See also Christopher A. Whytock \& Marcus S. Quintanilla, The New Multipolarity in Transnational Litigation: Foreign Courts, Foreign Judgments, and Foreign Law, 18 Sw. J. INT'L L. 31, 44-5 (2011)(noting that written secondary sources do not, alone, help to ascertain how foreign law is applied in action).

${ }^{205}$ Bodum 638-9. See also Roger J. Miner, The Reception of Foreign Law in U.S. Federal Courts, 43 Am. J. Comp. L. 581, 588 (1995) (recommending that judges weigh the testimony of foreign law experts as they do the testimony of scientific evidence experts); Matthew J. Wilson, Improving the Process: Transnational Litigation and the Application of Private Foreign Law in U.S. Courts, 45 N.Y.U. J. INT'L L. \& Pol. 1111, 1145-7 (2013). (saying that the concerns of partisan experts are over-exaggerated). 
subject-specific treatises that include analysis of foreign law. The Foreign Law Guide, Globalex, and the Law Library of Congress's Guide to Law Online explain the legal structure of foreign jurisdictions, identify official publications, and provide access to authentic government websites. ${ }^{206}$ But, existing databases do not provide names of foreign law experts and a means to assess their work product. Additionally, they do not provide certified translations of foreign law unless the foreign government has issued an official translation. On the other hand, our U.S. federal court dockets do offer a means to ascertain this information, but there isn't yet an efficient way to retrieve it. A reference source that extracts and organizes the foreign law and legal analysis submitted to our courts would respond to litigant and judicial complaints and would also avoid the embarrassment that results in judicial inconsistency. ${ }^{207}$

Of course, such a reference source is not without its faults. It may provide a "jumping off" point to finding foreign law and legal analysis through precedent, but it doesn't guarantee accuracy of the content of foreign law. There is a legitimate concern that litigants (or judges) might rely solely on what prior federal courts in prior cases concluded on the basis of the foreign law and legal analysis submitted to them. Yet, there is value in prior precedent. As one scholar noted in the 1980s (and it is even more true today):

"[w]ith the increasing number of foreign-law disputes confronting American courts, the use of prior domestic decisions is likely to expand. At least some weight should be given to these decisions. Indeed, in the typical situation where the opinions of party experts conflict, the careful reasoning of an earlier court confronting the same issue may be quite helpful." 208

FRCP Rule 44.1's acceptance of "any relevant material or source" obviously includes precedent. Plus, as noted earlier, improving the quality of party submissions of foreign law and legal analysis starts with identifying its current state. It helps to track what is happening in our courts before making an accuracy assessment. To that end, creation of a reference source that extracts the foreign law and legal analysis filed in our court dockets is as good a start as any.

\section{A. A Prototype: The Extraction Process}

So, how does one find the foreign law and legal analysis submitted to our courts? There are several options that, in combination, yield the most comprehensive product. None of the techniques described below are efficient, but in combination, they provide the best means available today to extract foreign law and legal analysis from our U. S. federal courts.

\section{Federal Docket Research}

Most cases settle long before they result in a judicial opinion. A docket search of federal cases captures cases in all stages of development whether ongoing, settled, or appealed. Even if one begins identifying relevant cases through editorial content or key word searches available through Westlaw or Lexis (see section 2, below), one must then turn to a docket search of the relevant cases to extract the foreign law and legal analysis filed within individual pleadings and accompanying exhibits. There are two subscription-based databases that provide the American legal academy with full-text access to all documents within the docket of a federal court case: PACER and Bloomberg Law.

\section{a. PACER}

PACER (Public Access to Court Electronic Records) is a U.S. government database provided by the Federal Judiciary that provides electronic public access to case and docket information from federal appellate, district, and bankruptcy courts. ${ }^{209}$ PACER offers an index service that allows users to search fields for docket numbers, case

206 There are also the freely-available, subject specific databases like WIPO-Lex and NATLEX, e.g.

207 See infra Part III. See also John G. Sprankling \& George R. Lanyi, Foreign Law in American Courts, 19 STAN. J. InT'L L. 3, 63 (1983) (citing six California decisions, all rendered over a seven-year period, split evenly on the simple issue of whether American citizens could inherit under German law).

${ }^{208}$ John G. Sprankling \& George R. Lanyi, Foreign Law in American Courts, 19 Stan. J. InT'L L. 3, 66 (1983).

$209 \mathrm{https} / / /$ www.pacer.gov/about.html. The program reached a milestone in fiscal year 2015 surpassing two million user accounts. 
names, party names, regions, and/or date ranges, but it does not permit keyword searching at all. ${ }^{210}$ Unless one already knows a particular case wherein one or more parties asserts foreign law, PACER is not an efficient means of extracting foreign law filed in our courts. Additionally, PACER is a subscription-based service, so all searches result in fees.

\section{b. Bloomberg Law}

Many of us in the American legal academy prefer Bloomberg Law for docket research because it provides full-text access to all PACER documents without additional PACER-related fees. More importantly, Bloomberg Law offers a keyword search functionality of all the documents filed within a case's docket, which are available in OCRscanned.pdf format. ${ }^{211}$ So, users on Bloomberg Law are not limited to the case name, party name, court, or date range fields; they may also use Boolean language to search federal court documents for individual pleadings filed in U.S. federal courts. ${ }^{212}$ As a disclaimer, Bloomberg Law's docket search function is clunky and it is not fully comprehensive, ${ }^{213}$ but a well-crafted keyword search offers a way to begin creating a reference source that extracts the foreign law and legal analysis filed in U.S. federal courts.

Since FRCP Rule 44.1 is the procedural rule that parties should use to raise issues of foreign law, a docket search should include Rule 44.1 as a keyword. A keyword search of: "federal rule! of civil procedure 44.1" OR "federal rule! of civil procedure rule 44.1" OR "fed. r. civ. pro. 44.1" OR "Fed.R.Civ.P. 44.1" OR "FRCP 44.1" OR "rule 44.1" NOT "PCT Rule 44.1" NOT "criminal rule 44.1" within U.S. Supreme, Appellate and District courts yields 549 cases filed within the last five years and fifty-seven cases filed within the last twelve months. ${ }^{214}$ This search is both over-inclusive and under-inclusive. It will provide results that cite an unrelated "rule 44.1" and it will fail to capture cases where parties raised foreign law without citing FRCP Rule 44.1. But, it is as good a search as one can craft to capture all the available FRCP Rule 44.1-related filings.

Of course, alternative options are to search "foreign law" or "law! of [foreign country]" or "[foreign country] law!" as keywords in a docket search of U.S. Supreme, Appellate, and District courts. A search of "foreign law," however, yields $1000+$ cases filed within the last five years and 432 cases filed within the last twelve months. Although it captures the most cases, this search is over-inclusive because it captures every case with a document that references foreign law, even if foreign law is not relevant to the case in any way. On the other hand, a search of "law! of France" OR "French law!" yields 484 cases filed within the last five years and only forty cases filed within the last twelve months. This search may be the best way to start compiling documentation of French law filed in U.S. court dockets, but it isn't an efficient way of finding documentation of the other 194 countries in the world.

Once one clicks on a result, Bloomberg Law provides the case's court docket and highlights in yellow the individual file(s) in the docket that cites the keyword(s) searched. If one conducts the FRCP Rule 44.1 search explained above, one confirms that parties raise issues of foreign law through FRCP Rule 44.1 throughout the process of litigation all the way up to trial. FRCP Rule 44.1 notices appear in complaints, responses, on their own in separate pleadings, in motions to dismiss for forum non conveniens, in summary judgment motions, in memoranda of law, in amicus briefs, in expert declarations, and/or in any other document filed with the courts. ${ }^{215}$ Each of these pleadings often contains citations and analysis of foreign law. Additionally, each of these pleadings often attaches as exhibits the primary and secondary sources of authority that guide the analysis in the pleadings. These exhibits hold the certified translations of foreign legislation, case law, regulatory law, treatises, legal journal articles, and any other source of authority in which parties rely.

To find foreign law and legal analysis filed in U.S. federal courts, one must perform the tedious task of reading the pleadings that cite FRPC Rule 44.1 (or "foreign law" or "law! of [foreign country] or "[foreign country] law!", depending on search performed) and all of the attached exhibits. Unfortunately, since Bloomberg

${ }^{210}$ See PACER User manual https://www.pacer.gov/documents/PCLUserManual.pdf

${ }^{211}$ Bloomberg Law's docket coverage does not, however, provide comprehensive coverage to state court dockets.

${ }^{212}$ See docket search function.

${ }^{213}$ Not all the individual pleadings seem to be OCR'd. For example, I tried to search Bundesgesetz über die Sanierung und Abwicklung von Banken knowing it appeared within an expert declaration in a particular bankruptcy case (in re Motors Liquidation), but Bloomberg Law yielded zero results.

214 The search was crafted to avoid bankruptcy and criminal cases.

${ }^{215}$ See e.g., Appendix. 
Law relies on PACER's metadata, the descriptions of documents filed in the court dockets are not sufficiently or consistently detailed. For example, it is rare for Bloomberg Law to describe a document in the docket as: [name of person], expert declaration on [foreign country] law. Rather, the metadata of exhibits attached to pleadings merely state: exhibit A. One must open exhibit A to find the [name of person] expert declaration on [foreign country] law. One cannot, therefore, save time by relying on document descriptions of pleadings filed in the court docket to know which foreign law is cited or analyzed in a pleading or included as an exhibit.

\section{Editorial Content \& Key Word Searches on Westlaw or Lexis}

Both Westlaw and Lexis Advance provide editorial content and advanced search functions that help identify some U.S. federal cases that involve issue(s) of foreign law. Neither of these databases, however, offer access to PACER or, by extension, full-text access to all the pleadings and exhibits that cite, analyze, and document foreign law filed in U.S. federal courts. ${ }^{216}$ As a result, to create a reference source that tracks foreign law and legal analysis submitted to U.S. federal courts, Westlaw and Lexis Advance provide means to supplement, but not replace, the docket research process described above.

\section{a. Citing References of FRCP Rule 44.1}

The Westlaw and Lexis Advance databases allow users to retrieve cases, statutes, administrative materials, trial court documents, and secondary sources that cite FRCP Rule 44.1. On Westlaw, FRCP Rule 44.1 has 7,247 citing references, of which 1,342 are cases. ${ }^{217}$ The Lexis Advance database offers 1,308 cases that cite to FRCP Rule 44.1. Both numbers are significantly under-inclusive. They only capture the rare number of cases that result in an order or opinion. As we know, however, most cases settle before ever reaching an order or opinion. Additionally, the case citing references on Westlaw and Lexis Advance only highlight those orders and opinions written by judges who cite to FRCP Rule 44.1. Not all judicial opinions are sufficiently detailed. Plus, if a judge cites to FRCP Rule 44.1 in her order or opinion, it could be because FRCP Rule 44.1 was a major component of the case and not just a procedural vehicle to submit documentation of foreign law and legal analysis. To clarify, the approximately 1,300 case citing references of FRCP Rule 44.1 on Westlaw and Lexis Advance are excellent places to start identifying cases in which one or more parties produced documentation of foreign law, but they do not provide the complete universe of cases.

Besides cases, Westlaw also offers trial court documents that cite to FRCP Rule 44.1, specifically 2,791 trial court documents, further sub-divided in the categories of: pleadings (701); motions, memoranda and affidavits $(2,020)$; transcripts (5); filings (30); depositions and discovery (2); verdicts and settlements (2); jury instructions (9); and expert materials (22). Again, these are a fantastic start to creating a reference source that extracts the foreign law and legal analysis filed in U.S. federal courts because they help identify case records citing FRCP Rule 44.1. Unfortunately, however, Westlaw does not yet provide comprehensive coverage of all documents filed in U.S. federal court, so the trial court documents provided only represent the tip-of-the-iceberg. More importantly, for our purposes, Westlaw does not provide the exhibits attached to any of the trial documents. As explained throughout this article, the exhibits are often the documents that provide the foreign law and legal analysis. Until Westlaw offers full access to PACER for all trial documents, including exhibits, its citing references will not accurately reflect all of the FRCP Rule 44.1-related documents submitted to our courts.

\section{b. Digests}

Both Westlaw and Lexis Advance offer digest services. Westlaw, of course, has a key number system and Lexis Advance has a breadcrumb trail. Both systems focus on grouping like cases together based on their headnotes and both systems provide alternative, but still incomplete, ways to identify cases involving issue(s) of foreign law. These systems identify cases beyond just those with orders or opinions that specifically cite to FRCP Rule 44.1, but they do not provide access to the case exhibits where the foreign law and legal analysis are found. Moreover, Westlaw and Lexis Advance do not provide headnotes for every order and opinion included in their case databases

\footnotetext{
${ }^{216}$ Westlaw offers a dockets search option to academic subscribers, but does not provide full-text access to all the documents within all U.S. federal court dockets.

${ }^{217}$ Search as of $8 / 27 / 18$.
} 
and, without headnotes, a case will not be captured by a digest search. Again, to reiterate upon a theme, Westlaw and Lexis Advance provide wonderful ways to begin creating a reference source that extracts and organizes foreign law because they help identify some cases that involve foreign law. But, efforts on Westlaw and Lexis Advance must be followed with docket research because only through full-text access to the docket will one find the foreign law and legal analysis submitted to our courts.

There are several key numbers on Westlaw that yield cases involving foreign law. For example, under the topic of Evidence (157), key number 37 yields 390 headnotes on judicial notice and the laws of foreign countries ${ }^{218}$ and key number 81 yields 241 headnotes on presumptions with regards to the laws of foreign countries. ${ }^{219}$ There are also a handful of other topics and key numbers that help identify cases involving foreign law. For example, the topics and key numbers: action (13k17), ${ }^{220}$ courts (106k9), ${ }^{221}$ international law $(221 \mathrm{k} 10.8),{ }^{222}$ and trial (388k136(4)) ${ }^{223}$ also gather headnotes from cases that discuss foreign law in some way.

Similarly, Lexis Advance's breadcrumb trails assemble some cases that discuss foreign law beyond those orders and opinions that specifically cite to FRCP Rule 44.1. Under the topic of evidence, Lexis Advance compiles 704 headnotes on judicial notice and legislative facts regarding the laws of foreign states. ${ }^{224}$ Also, under the topic of public contracts law, Lexis Advance shows twenty-two headnotes regarding contract interpretation and foreign law. 225

\section{c. Key Word Searches}

Lastly, and most obviously, Westlaw and Lexis Advance provide fantastic keyword search functions to cast an even wider net of cases involving foreign law. A keyword search involving FRCP Rule 44.1 will yield similar results to the citing references search performed above, but a keyword search of "foreign law" within the federal case databases of Westlaw and Lexis Advance gives 10,000 and 9,787 results, respectively. On the other hand, a keyword search of "law! of France" OR "French law!" within all federal cases yields 1,719 cases on Westlaw and 1,313 cases on Lexis Advance. To state the obvious, however, the keyword searches are only trawling the words used by federal judges in their orders and opinions (or in the limited court documents Westlaw provides academic subscribers), so these searches are not as inclusive as their numbers suggest even if they are a means of beginning to identify cases in federal court that involve foreign law.

\section{B. A Prototype: The Organization Process}

As explained above, the extraction process associated with creating a reference source that tracks foreign law and legal analysis filed in U.S. federal courts involves cobbling together several searches on Bloomberg Law, Westlaw, and Lexis Advance. These searches identify cases involving foreign law and also locate documents of foreign law and legal analysis filed in U.S. federal courts. Relatedly, the organization process begins simultaneously with the extraction process and asks: how should the information be organized to be of maximum assistance to future researchers? Without having a guaranteed answer to this question, the prototype attached as an appendix to this article offers one example of how to offer a finding aid of foreign law and legal analysis filed in our federal courts. ${ }^{226}$

Litigants (and judges) working on a case involving foreign law will naturally turn to sources organized first by foreign sovereign. For this reason, the first column in the attached appendix holds the name of a foreign sovereign, in alphabetical listing A-Z. Next, the second column identifies the category of case, based on the taxonomy in Part II. The remaining fields provide: the name and docket information of a case (column 3); a case summary and the context in which foreign law was filed (column 4); and, finally, the particular document numbers within the case docket that host the foreign law and legal analysis (column 5). This final column includes the names of any experts construing

\footnotetext{
$218157 \mathrm{k} .37$ has 390 headnotes of all state and federal courts as of $8 / 27 / 18$.

$219157 \mathrm{k} 81=241$ headnotes of all state and federal courts as of 8/27/18.

${ }^{220} 13 \mathrm{k} 17=6659$ headnotes of all state and federal courts as of 8/27/18.

$221106 \mathrm{k} 9=225$ headnotes of all state and federal courts as of $8 / 27 / 18$.

$222221 \mathrm{k} 10.8=2046$ headnotes of all state and federal courts as of 8/27/18.

$223388 \mathrm{k} 136(4)=178$ headnotes of all state and federal courts as of 8/27/18.

224 Evidence $>$ Judicial Notice $>$ Legislative Facts $>$ Laws of Foreign States.

225 Public contracts law $>$ contract interpretation $>$ foreign law.

${ }^{226}$ I organized the original appendix in Excel, but converted it to Word format for publication.
} 
foreign law as well as their CVs attached to their expert declarations. Of course, this column also includes the expert's actual analysis as well as any primary or secondary foreign legal sources relied upon by the expert (or counsel). Naturally, all of these documents are translated into English by party agents.

As an example, a litigant (or judge) in a contract interpretation case involving Afghan law would first find "Afghanistan" and then "choice of law." After that, the litigant (or judge) would browse the case names and summaries to find relevant precedent. Once precedent was located, to find documentation on Afghan law and legal analysis (including expert testimony on Afghan law), the litigant (or judge) would use Bloomberg Law to find the document numbers within the case dockets that provide the Afghan law. To use the Rose v. Computer Sciences Corp. case in the attached appendix, which is a choice of law case involving Afghan law, docket document \#82 provides defendant's motion for partial summary judgment. Attached to defendant's motion as exhibits is an expert declaration by Reema Ali as well as translated selections of the Civil Law of Afghanistan. Future researchers of Afghan law may find these documents useful for their own practice or scholarship.

The appendix attached to this article is only a first attempt at creating a prototype for a reference source that tracks the foreign law and legal analysis filed in U.S. federal courts. It is not the only way or the best way. Also, it analyzes only a random sample of cases found through the various searches in Bloomberg Law, Westlaw, and Lexis Advance, described above. One of the biggest challenges to creating the reference source (other than time and resources) would be to decide on the depth of detail to include in column 5. The goal is to provide enough information about the foreign law and legal analysis found in a docket document without listing every section of every piece of foreign legislation provided in an exhibit or cited in a pleading. But, the appendix is an offer to begin a conversation among law librarians in the academy to develop a more comprehensive source that tracks and organizes the foreign law filed in U.S. federal courts.

\section{Conclusion}

The purpose of this article is to raise awareness about the increasing amount of foreign law and legal analysis filed in our courts and to argue that some type of source should exist to track and organize it. Offering access to foreign law and legal analysis already filed in prior precedent would provide future researchers with a "jumping off' point to foreign legal research that supplements existing foreign legal research databases and, of course, print library holdings. Additionally, by performing a tacking service, litigants (and judges) would be able to identify foreign law experts and assess their work product. Moreover, a compilation of all the foreign law and legal analysis filed in our courts would lead to an accountability mechanism to improve the accurateness of party submissions and expert conclusions. Lastly, parties who cannot afford to hire experts and find and translate foreign law would have access to the foreign law and legal analysis already acquired by wealthy parties, promoting equal access to justice.

But, who or what is in the best position to create such a source? Ideally, the platforms that provide full-text access to federal court dockets (PACER, Bloomberg Law) would develop an algorithm to capture and catalog the foreign law and analysis that parties submit to the federal courts. Until that happens, however, academic librarians with full access to the federal dockets should take responsibility. Given the sheer number of cases considering foreign law in our federal dockets, however, one librarian cannot do it alone. A group should form to explore crowdsourcing strategies and/or grant funding options. The reference source could be a way for academic law librarians to support the research needs of firm and government law librarians as well as legal practitioners and scholars.

\section{Appendix}

The following appendix is a prototype for a reference source that tracks the foreign law and legal analysis submitted to U.S. federal courts. It acts as a finding aid to the names and work product of experts in foreign law and to the English-language versions of primary and secondary foreign legal sources relied on by parties and their experts. The appendix focuses on a random sample of cases discovered through the various searches conducted on Bloomberg Law, Westlaw, and Lexis Advance, described in Part IV, above. 


\section{APPENDIX}

This appendix is a prototype for a reference source that tracks the foreign law and legal analysis submitted to U.S. federal courts.

\begin{tabular}{|c|c|c|c|}
\hline $\begin{array}{l}\text { Foreign State } \\
\text { or Territory }\end{array}$ & Case Type & Case Name/Docket No. & Case Brief \\
\hline Afghanistan & $\begin{array}{l}\text { Choice-of- } \\
\text { Law }\end{array}$ & $\begin{array}{l}\text { Case Name: Rose } \\
\text { v. Computer Sciences } \\
\text { Corporation } \\
\text { Docket: } 2: 15-\mathrm{cv}-00813 \\
\text { (E.D. La., Mar. 13, } \\
\text { 2015). }\end{array}$ & $\begin{array}{l}\text { Breach of (employment) contract case } \\
\text { in federal court based on diversity } \\
\text { jurisdiction. Plaintiffs are U.S. citi- } \\
\text { zens hired by defendant, a U.S. } \\
\text { military contractor, to work overseas } \\
\text { in Afghanistan, Iraq, and Kuwait. In } \\
\text { their complaint, Plaintiffs argued } \\
\text { that the contract law of Virginia } \\
\text { governed their claims because } \\
\text { Defendant's headquarters and prin- } \\
\text { cipal place of business are in } \\
\text { Virginia. Defendant argued that the } \\
\text { contract law of the foreign country } \\
\text { in which the employee performed } \\
\text { his/her contract (Afghanistan, Iraq, } \\
\text { or Kuwait) should govern Plaintiffs' } \\
\text { individual claims. }\end{array}$ \\
\hline
\end{tabular}

\section{Case Names and \\ Dockets [all related]}

Aranda et al. v. Philip

Morris USA Inc.

Docket No. 525,2016

(Del. Oct. 27, 2016);

Hupan v. Philip Morris

USA Inc., Docket No.

526,2016 (Del. Oct.

27, 2016); Biglia

v. Philip Morris USA

Inc., Docket No.

527,2016 ((Del. Oct.

27, 2016)) Chalanuk

v. Philip Morris USA

Inc., Docket No.

528,2016 (Del. Oct.

27, 2016); da Silva

v. Philip Morris USA

Inc., Docket No.

529,2016 (Del. Oct.

27, 2016); Taborda

v. Philip Morris USA

Inc., Docket No.

530,2016 (Del. Oct.

27, 2016)

Delaware Superior (trial)

Court): Hupan

et al. v. Alliance One

Internat'l, Inc. et al.,

Docket No. N12C-02-

171 (Del. Super. Ct.

Feb. 14, 2012);
Docket Documents that Identify/Analyze Foreign Law

Docket Document \#82 (filed July 18, 2017). Defendant's Motion for

Partial Summary Judgment as to the Controlling Law (with exhibits).

Document 82-6 is an expert declaration (Reema Ali), which identifies and analyzes the general rules of contract formation and interpretation under the laws of Kuwait, Iraq, and Afghanistan. Also as exhibits are translated selections of: the Civil Code of Kuwait (Document 82-7); the Law of Labor in the Private Sector in Kuwait (from url http://www. kuwaitlaborlaw.com) (Document 82-7); The Civil Code of Iraq (Document 82-8); and the Civil Law of Afghanistan (Document 82-9).

Docket Document \#124 (filed Oct. 18, 2017): Supplemental. Memorandum by [defendant] in support of Motion for Partial Summary Judgment as to the Controlling Law.

Docket Document \#128 (filed Oct. 22, 2017). Plaintiff's Supplemental on the Choice of Law Issue. In the text of the Supplemental Memorandum, Plaintiff analyzes the document \#82 and its exhibits (see above). Additionally, in footnotes of the Supplemental Memorandum, Plaintiff cites: a different law review article by Dan E. Stigall, From Baton Rouge to Baghdad: A Comparative Overview of the Iraqi Civil Code, 65 LA. L. REv. 131 (2004); and the Wikipedia page for "The Iraqi Civil Code" (https://en.wikipedia.org/Law_of_Iraq).

Consolidated appeals at Delaware Supreme Court. Plaintiffs, Argentinian farmers, owned or lived on family-farms in Argentina. In addition to raising livestock and growing produce for their own consumption, the Argentinian farmers also grew tobacco for one of Philip Morris's subsidiaries. As required by Philip Morris, the Argentinian farmers used a Monsanto-created herbicide ("Roundup") on the tobacco fields without knowing that the herbicide causes "genetic, teratogenic and/or developmental injury to humans." Delaware is the place of Philip Morris's incorporation. Philip Morris filed a motion to dismiss for forum non conveniens, arguing that it would be too burdensome for Philip Morris to litigate the case in Delaware when the evidence is in Argentina and Argentina's laws will apply to the case (the parties had agreed that Argentine law would govern substantive issues, but disagreed as to whether it would apply to negligence and punitive damages claims).

NOTE: The parties exchanged documents relating to Argentinian law and legal analysis at the trial stage of litigation. Of the six (6) [related] cases at the Delaware Superior (trial) Court, the Hupan docket (Docket No. 12C-02-171) provides the most comprehensive list of docket documents. The documents below are from the Hupan docket on Bloomberg Law.

Docket Document \#175 (filed Feb. 8, 2013): Affidavit of Kelly E. Farnan. In the affidavit, defense counsel provides "true and correct cop[ies] of certified translations of Argentine Law with Spanish originals." The Argentine law provided in these certified English/original Spanish versions include: Art. 161 of the Bankruptcy Law (Law 24.522 of 1995); Arts. 54, 82, and 83 of the Business Corporations Law (Law 19.550); an extensive variety of articles from the Civil Code of Argentina; selected articles from Argentina's Consumer Protection Law (Law 24.240 of 1993) with amendments; selected articles from Argentina's Law 26.579 (Age of Majority); selected articles from the Law on Labor Contracts (Law 20.744 of 1974, with text of Decree 390 of 1976); Art. 303 of the National Code of Civil and Commercial Procedure; and Arts. 45 and 46 of the Penal Code of Argentina.

Docket Document \#176 (filed Feb. 8, 2013): Affidavit of Keith $\mathrm{S}$. Rosenn. This is an expert declaration that provides a brief overview of the Argentine legal system and then analyzes liability and damages available under Argentine contract law, tort law, corporate law, and criminal law.

Docket Document \#177 (filed Feb. 8, 2013): Appendix in support of Keith S. Rosenn's Affidavit. Appendices include English and Spanish versions of: Article 303 of the National Code of Civil and Commercial Procedure (Spanish version from the Argentinian database/website: www.infoleg.gov.ar); the Consumer Protection Law; the Argentine Civil Code; the Business Corporation Law; the Bankruptcy Law; the Law of Labor Contracts; Law 26.573 of 2009 (Age of Majority); selected articles from the Penal Code.

Docket Document \#195 (filed May 6, 2013): Appendix 1 - Declaration of Alejandro M. Garro. This document is an expert declaration from Plaintiffs' expert. In his affidavit, Mr. Garro analyzes all of the Argentinian legislation cited above in the context of this case.

Docket Documents \#196 \& 197 (filed May 6, 2013): Exhibit A - Parts 1 and 2 of expert declaration (Alejandro M. Garro). This exhibit provides the transcript of the deposition of defendants' expert, Keith Rosenn, where he explains his analysis of Argentine legislation.

Docket Document \#199 (filed May 6, 2013): Exhibit C of expert declaration (Alejandro M. Garro) provides an English version of the Constitution of the Argentine Nation, downloaded off the website: www.senado.gov.ar.

Docket Document \#209 (filed July 15, 2013): Affidavit of [defense counsel] Katherine C. Lester. Document 209-2 provides exhibits A-D of Lester's Affidavit. Exhibit A is the transcript of the deposition of 


\section{APPENDIX}

\section{Continued}

Foreign State or Territory
Case Type

Case Name/Docket No.

Case Brie
Docket Documents that Identify/Analyze Foreign Law

Plaintiffs' expert, Alejandro M. Garro, where he explains his analysis of Argentine law.

Docket Documents \#283 AND \#284 (filed Apr. 29, 2014):

Compendiums, Parts 1 and 2, of unreported decisions and foreign authorities cited in Defendants' Opening Brief in support of Motion to Dismiss based on Forum non Conveniens. Compendium (B1) includes English versions of all sources cited by Defendants' expert, Alfredo L. Rovira. These include: Article 12 of Law 22.172; several articles of the Argentine constitution; several articles of the Argentine Civil Code; Article 1 of the Argentine Consumer Protection Law (Law 24.240); Article 54 of the Business Corporations Law (Law 19.550); Article 25 of the Organic Law of the Public Ministry (Law 24.946); a few articles from the Civil and Commercial Procedures Code; Article 2 of Law 23.480; Articles 142 and 144 of the Constitution of Misiones Province; Article 2 of the Regulations of the Toxic Agrochemicals Act (Decree $2,867 / 93$ of the Province of Misiones; and several articles of the Organic Law of the Judiciary of the Province of Misiones (previously Decree/Law 1,550/82). Compendium documents B2-B12 provide selections of treatises, cases, and articles published in Spanish and translated (for the instant case) into English. Those treatises include: (B2) Civil and Comercial Code Procedures (Morello, Sosa, \& Berizonce); (B3) A Treatise on Civil Law (Borda); (B4) Civil Code and Supplementary Laws (Bueres); (B5) Argentina Supreme Court Case of "Carballo de Pochat"; (B6) InterAmerican Court of Human Rights case N. AP/JUR/3074/2012; (B7) Argentina Supreme Court "Faifman" case; (B8) article titled "The exercise of jurisidiction under the new Civil and Commercial Procedural Code of the Nation" (Olmedo); (B9) Treatise on Civil Law (Llambias); (B10) Argentina Supreme Court case "Manzoratte"; (B11) Civil Code Commentary (Rivera); (B12) Argentina Supreme Court case "Rivera".

Docket Document \#287 (filed Apr. 29, 2014): Declaration of Dr. Alfredo L. Rovira. This is an expert declaration where expert construes all the Argentine law provided in the compendium cited above (B1).

Docket Document \#299 (filed Apr. 29, 2014): Compendium. In this compendium, Defendants provide English translations and original Spanish versions of the following: Article 42 of the Argentine constitution; Article 54 of the Business Corporation Law (Law 19.550); several articles of the Civil Code; several articles of the Consumer Protection Law (Law 24.240); selections of Treatise on Civil Law (Borda); ruling from the Argedine Appeals Court in Civil Matters "Canadas Perez Maria vs. Bank Boston NA for damages; selections of commentary on Consumer and User Protection (4th ed., Farina); selections from treatise Civil Liability as Strict Liability in Tort and Company Risk (Pizarro); Spanish Supreme Court Civil Chamber decision (STS 4319/1999).

Docket Document \#321 (filed Oct. 14, 2014): Exhibits 1-22 of Plaintiffs' Combined Opposition to Defendants' Motion to Dismiss on grounds of Forum non Conveniens. Exhibit 1 provides the second declaration of [expert] Alejandro M. Garro. Exhibit 21 is the transcript of the deposition of defendants' expert on forum non conveniens (Alfredo Rovira).

Docket Document \#329 (filed Jan. 13, 2015): Compendium of Foreign Authorities cited in Defendants' Reply Brief in support of its Motion to Dismiss. The compendium includes English and Spanish versions of: Article 1 of the Argentine Civil Code; Article 65 of the Consumer Protection Law (Law 24.240); selections of the treatise on Civil Law (Borda); selection of Parts 3 and 4 of treatise on Consumer Protection (Lorenzetti et al.).

Plaintiff is an institutional investor that holds beneficial interests in defendant-issued bonds. Some of the bonds are governed by German law and others are governed by New York law. In 2001, after an economic crisis, defendant stopped making scheduled payments on its bonds, triggering defaults on Plaintiff's German and New York bonds.
Docket Document \#19 (filed May 4, 2017): Declaration of Lydia Ferrarese (with exhibits). Document 19-2 is a declaration by an expert (Oliver Sieg) of German law. The expert construes various sections of the German Civil Code (Burgerliches Gesetzbuch, BGB) and cites various sources of commentary (from treatises and case law) regarding the statute of limitations period for debtor claims under German law. 